\title{
Rethinking the defining contextualization of in-work poverty: the challenge of individualism and globalization
}

\author{
Jinghong Liu* (D)
}

\section{*Correspondence:}

018189@nankai.edu.cn;

liujinghong3226459@gmail.

com

Zhou Enlai School

of Government (ZSG), Nankai

University, No.38 Tongyan

Road, Jinnan District,

Tianjin 300350, People's

Republic of China

\begin{abstract}
Growing empirical evidence reveals the dramatic expansion in the risk of in-work poverty on a global scale over the last half-century. The current article reviews research on in-work poverty, illustrates how in-work poverty developed from a regional phenomenon into a global issue, and considers recent studies that have reexamined the concept of "in-work poverty" from the original "male family head" to further call on respecting the individual perspective and gender dimension. On the one hand, few studies have provided evidence on the gendered trends in in-work poverty; women's situation in inwork poverty has not been particularly researched, and the gender dimension is often invisible. On the other hand, the existing literature does not consider this poverty issue much in developing countries, even though this does not mean that in-work poverty in developed countries is only a "side effect." Hence, an international comparative setting with the gender dimension is needed, and more research is required to explore this construct within the context of the developing world.
\end{abstract}

Keywords: In-work poverty, Individualism, Gender dimension, Globalization

\section{Introduction}

As early as the 1960s, the United States (US) began to pay attention to the poverty issue in employment, followed by Canada and Australia. At the beginning of the twenty-first century, this problem received increased attention in political and academic debates at the European level. Since then, there has been a growing interest in researching in-work poverty worldwide, and previous literature has provided a fertile ground for defining, measuring, and describing this particular poverty issue.

On a global scale, close to an estimated 776.2 million workers live with their families on less than $\$ 3.1$ per person per day, accounting for $28.7 \%$ of workers throughout the world (ILO 2017). In the US, approximately 9.5 million individuals are among the working poor, which comprises $6.3 \%$ all individuals in the labor force (U.S. Bureau of Labor Statistics 2014). These are the working people whom Vance described as "the poor white working-class 'hillbilly"' (Vance 2016), or they may be the people of color and immigrants who work in low-quality jobs.

(C) The Author(s), 2022. Open Access This article is licensed under a Creative Commons Attribution 4.0 International License, which permits use, sharing, adaptation, distribution and reproduction in any medium or format, as long as you give appropriate credit to the original author(s) and the source, provide a link to the Creative Commons licence, and indicate if changes were made. The images or other third party material in this article are included in the article's Creative Commons licence, unless indicated otherwise in a credit line to the material. If material is not included in the article's Creative Commons licence and your intended use is not permitted by statutory regulation or exceeds the permitted use, you will need to obtain permission directly from the copyright holder. To view a copy of this licence, visit http:// creativecommons.org/licenses/by/4.0/. 
On the other side of the Atlantic, in-work poverty is a Europe-wide phenomenon, which requires specific policy attention from governments and social partners (Eurofound 2017; Lohmann and Marx 2018). Eurostat data indicate that the working poor has shown a slight but stable increase in recent decades (Gutiérrez et al. 2011); this phenomenon has already affected 10\% of European workers (Eurofound 2017) and involved no less than approximately 20 million European workers (Eurostat 2016).

As evidenced by these international figures, in-work poverty can be considered a worldwide phenomenon. In a sense, it is a part of globalization as well. Today's global formations are diverse, both as social forms (e.g., the global capital markets, international human rights) and normative orders (Sassen 2007). In this global formation, in-work poverty is becoming a complex phenomenon that is actively "unbundled" worldwide, thereby also challenging Chinese society; the difference is the scope of how this kind of poverty works in correspondence with the particularities of each nationalstate context. As Saskia Sassen argued, "Globalization in its many forms directly engages two key assumptions in the social science. The first is the explicit or implicit assumption about the nation-state as the container of social process. The second is the implied correspondence of national territory with the national" (Sassen 2007: 3). The in-work poverty issue can (of course) be specifically localized, but it can also be more globalized and interconnected under the conditions of the international division of labor in a growing number of nations; China, for instance, currently plays an important role in this dynamic. In this way, the working poor is part of a global labor market, and many "containers" are now under international pressure.

This fact has motivated considerable research on this poverty issue in general, particularly at the national level. Nevertheless, only limited information is available internationally on the in-work poverty phenomenon and about how far research has come in the last few decades. The relevant literature review on in-work poverty embedded at the global level has been small and probably inchoate. On this premise, the major concern is with the reexamination of how we contextualize in-work poverty in ways that allow us to develop a conceptual lens to define this phenomenon in the research properly. This problem is addressed by broadly reviewing the literature related to this topic. By reviewing the existing literature from a historical perspective, we try to offer an interpretative framework that we can use to capture the direction and changes of this poverty issue over the past half-century and proceed with constructing a global version of the working poor.

The topics of this systematic literature review are the concept-being process and research trends of in-work poverty. The review was carried out in two steps: a conceptualizing exercise followed by an in-depth review of the research trends of in-work poverty. The first step provided the conceptual basis for the systematic review of research and located a wide variety of relevant research for multiple dimensions of this poverty issue and its policy actions. Only those study findings and conclusions relevant to the review were extracted for potential inclusion in step two. Thus, we focus on those studies that define the norm of "in-work poverty," describe its sociodemographic profile, and provide socioeconomic causes.

The purpose of this paper is threefold. First, it profiles the concept-being process of in-work poverty and presents a historical overview of how in-work poverty is defined 
and conceptualized within the literature. It reveals the continuous evolution of the conceptualization of in-work poverty, which is a process that is conditioned by particular time and space contexts. Next, it canvasses the history of in-work poverty research and details the background and development trends of this phenomenon. Finally, it sketches out key trends of the in-work poverty research, focusing on the challenges of individualism and the gendered tendencies of this issue, the process of which is conditioned by particular time and space contexts.

According to the review, the paper reveals the six current trends of the in-work poverty research: (1) work is no longer effective at avoiding poverty; (2) the trend of market reconstruction calls for family-targeted policies and assistance for the informal sector; (3) there is a lack of attention in developing countries to research on the working poor; (4) working poor studies have usually underrepresented the gender dimension; (5) lowincome workers are often targeted in research on the working poor, while women in low-income jobs are underresearched; and 6) the factors that impact the working poor and how to affect such social issues have not yet been explored in detail. Furthermore, the review illustrates how in-work poverty developed from a regional phenomenon into a global issue and how recent studies reexamined the concept of "in-work poverty" from the original "male family head" perspective to further incorporate an individual perspective and gender dimension. On the one hand, few studies have provided evidence on the gendered trends in in-work poverty; women's situation in in-work poverty has not been particularly researched, and the gender dimension is often invisible. On the other hand, the existing literature focuses little on this poverty issue in developing countries, even though this does not mean that in-work poverty in developed countries is merely a "side effect." Based on the above, an international comparative analysis with a gender dimension is needed for future research and policy implementation.

\section{Contextualizing "working poor" over time and space}

In recent years, there has been a growing interest in the in-work poverty (IWP) phenomenon worldwide. However, when we compare it to the extensive research on contextual issues around low pay, poverty in general, and inequality, the literature on IWP seems not to be especially fruitful. Relying on the corpus of social science articles published in English (with terms such as "working poor," "in-work poverty," or "working poverty" included in article titles in the Google Scholar database), we find that there are over 2,000 pieces of literature specifically on the topic of in-work poverty, but only 18 publications when "women" or "female" is added to the IWP titles (Table 1).

Table 1 Literature on in-work poverty (1965-2018)

\begin{tabular}{lc}
\hline Titles & $\begin{array}{c}\text { Pieces of } \\
\text { literature }\end{array}$ \\
\hline Working poor & 1,802 \\
In-work poverty & 185 \\
Working poverty & 135 \\
Female working poor & 3 \\
Working poor women & 15 \\
\hline
\end{tabular}


What is in-work poverty? The lack of clarity about this phenomenon is a real problem that must be addressed. There is no universal definition of in-work poverty (or working poor) in most literature. While various studies conceptualize it using different priorities, and different countries employ different approaches, seen in a historical light, what is today called in-work poverty (or working poor or a number of other terms) has always existed. Defining a concept cannot be separated from the specific context, while at the same time, a definition of a concept should inevitably withstand the limitations of time. In comparative research across societies and cultures, social phenomena needs to be understood with specific context, the context-boundedness of concepts builds a social basis for comparative analysis (Grootings 1986). In this sense, the core concept of the "working poor" could be a context-bounded concept.

Several key definitions or concepts emerge from the literature on in-work poverty, which suggests a conceptualized process of the working poor over time and space. We retrieved key descriptions to convey the temporal and spatial meanings of in-work poverty (Tables 2 and 3). The significance of this approach is the capture of multiple constructions of the "working poor" in a historical, dynamic way, the contexts of which can be seen through the different understandings it has had through time. Some of these key descriptions are different from each other; by detecting these differences, we are conducting an extensive "scan" of the field of all possible forms of in-work poverty. The field is still seeking to define, or redefine, this phenomenon through its diverse nature in a developing, dynamic way. Otherwise, considering language differences linked to specific history, values, and ideology, we abstract the keywords using their own language in the review of relevant literature and try to find a nearest approximation. In summarizing these definitions, there are three critical changes in the process of defining in-work poverty.

From a regional phenomenon to a global issue. Since the early 1970s, poverty has become prominent among individual full-time wage earners in America, approximately 2.9 million poor workers worked full-time (Wachtel and Betsey 1972). Later, in Europe, a new indicator of "in-work poverty risk" was added to the European portfolio of social indicators in 2003, highlighting the relationships between work and well-being as the core of the relevant discussion (Ponthieux 2010). In short, public debates began to pay more attention to the in-work poverty phenomenon starting in the 2000s, and scholars described in-work poverty as a reemergence phenomenon and a booming demographic, focusing on the strong growth and international trends of the working poor in labor markets.

Since the 2010s, by focusing on a comparative approach, research on in-work poverty has transformed from the regional level to a far more global level (Lohmann and Marx 2018). Andress and Lohmann, for example, observed the multiple facets of in-work poverty across welfare regimes within Europe (Andress and Lohmann 2008). Fraser et al. (2011) drew a profile of the worldwide working poverty by examining national variations and cross-cutting themes between the EU and the US. In addition, Pradella (2015) proposed an international political economy (IPE) perspective to understand the economic and international dimensions of IWP (Pradella 2015). In the 2010s, such poverty issues were recognized in Asian economies. For instance, Fields (2012) researched the global 
Table 2 Key definitions or conceptions in in-work poverty research (1965s-2000s)

\begin{tabular}{|c|c|c|c|}
\hline \multicolumn{2}{|c|}{$\begin{array}{l}\text { Concept over } \\
\text { Time and space }\end{array}$} & \multirow{2}{*}{$\begin{array}{l}\text { Key descriptions } \\
\text { (1) Male family heads, family income } \\
\text { (Greenberg and Kosters 1970; Tella 1971); } \\
\text { (2) Being poor while working (Miller } \\
\text { 1970); individual full-time wage earner } \\
\text { (Wachtel and Betsey 1972); Low-paid } \\
\text { work force (Bluestone et al. 1973); a mar- } \\
\text { ginal level of existence (Abbott 1980) } \\
\text { (3) Black, minority workers in low-wage, } \\
\text { low-skill Jobs (Nickson and Karp 1974; } \\
\text { Frankovic 1976) }\end{array}$} & \multirow{2}{*}{$\begin{array}{l}\text { Specific context } \\
\text { (1) Societal: Social protection systems } \\
\text { (Family Assistance Plan and Food Stamp } \\
\text { Program (FAP-FSP)); sociodemographic } \\
\text { structures (ethnicity: black); } \\
\text { (2) Social institutions (academicians) } \\
\text { (3) Individual: well-being, mentality } \\
\text { (health) }\end{array}$} \\
\hline 1965s-1980s & US & & \\
\hline & Canada & $\begin{array}{l}\text { Low-income Canadians (National Council } \\
\text { of Welfare 1987) }\end{array}$ & $\begin{array}{l}\text { Societal: sociodemographic structure } \\
\text { (profile of working poor) }\end{array}$ \\
\hline & France & Working poor (Scardigli 1970) & National: legal framework (social polices) \\
\hline & Kenya & Unrewarding employment (Leys 1973) & National: labour markets \\
\hline \multirow[t]{3}{*}{$1980 s-2000 s$} & US & $\begin{array}{l}\text { (1) Women's unpaid housework (Moser } \\
\text { and Young 1981; Willen 1988); women's } \\
\text { position in informal sector, flexible } \\
\text { work (Noponen 1992; De Wolff 2000); } \\
\text { immigrate women (Weitzman and Berry } \\
\text { 1992); low-waged women workers } \\
\text { (Figart and Lapidus 1995) } \\
\text { (2) Survival between work and family: be } \\
\text { loving and caring parents and produc- } \\
\text { tive efficient workers (Shiu 1989); single- } \\
\text { parent with children (Kim 1998) } \\
\text { (3) Economic hardship (Klein and Rones } \\
\text { 1989); low-income families (Shapiro } \\
\text { and Greenstein 1990); working-poor } \\
\text { household (Craypo and Cormier 2000); } \\
\text { labouring for Less (Shapiro 1989) } \\
\text { (4) A missing element in welfare reform } \\
\text { (Levitan and Shapiro 1987) }\end{array}$ & $\begin{array}{l}\text { (1) Societal: gender; family; health insur- } \\
\text { ance; state-subsidized childcare } \\
\text { (2) National: work and family policies; } \\
\text { health care polices; tax polices (Earned } \\
\text { Income Tax Credit); labour market (occu- } \\
\text { pational hierarchy); }\end{array}$ \\
\hline & Europe & The uninsured (Darling and Bass 1987) & National: federal policy \\
\hline & Asia Pacific & $\begin{array}{l}\text { Female poverty in India (Gulati 1981); } \\
\text { Work long hours for a meagre income } \\
\text { (Siddiqui 1990)-Nepal, Pakistan, Philip- } \\
\text { pines, Bangladesh }\end{array}$ & $\begin{array}{l}\text { Societal: gender } \\
\text { National and Global: labour law in cross- } \\
\text { national analysis }\end{array}$ \\
\hline
\end{tabular}

poverty as a problem of the quality of employment in 14 countries including China, India, Vietnam, Brazil, the US, and Mexico.

From a single discipline to multi-context analysis. We also read vivid descriptions of IWP's defining characteristics, for instance, "working but poor" or "laboring for less," thereby recognizing its main characteristics as earned-income insufficiency (e.g., "lowincome workers," "economic hardship," "the bottom of the income distribution"), poor job quality (e.g., "low-paid," "unrewarding," "most vulnerable workers," "working a long time for a meager income"), and insecure conditions (e.g., "working, uninsured adults").

Relatedly, in-work poverty issues have been broadly discussed from four more concrete perspectives. (1) Ethnic or gender discrimination focuses on black people, minority workers with low-skill jobs, or immigrant women. (2) Social exclusion examines how the working poor seem to have a marginal level of existence (Abbott 1980), working out of social security as the uninsured (Darling and Bass 1987; Nolan and Christie 2017), and even being a missing element in welfare reform (Levitan and Shapiro 1987). Based on this, a growing body of scholarship has located this issue within the context of the 
Table 3 Right words/Key terms in in-work poverty research (2000s-2017)

\begin{tabular}{|c|c|c|c|}
\hline \multicolumn{2}{|c|}{$\begin{array}{l}\text { Concept over } \\
\text { Time and space }\end{array}$} & \multirow{2}{*}{$\begin{array}{l}\text { Key descriptions } \\
\text { (1) Lowest stratum of economic } \\
\text { attainment (Shipler 2005); } \\
\text { (2) Ending welfare as we know it } \\
\text { (Duncan et al. 2007) }\end{array}$} & \multirow{2}{*}{$\begin{array}{l}\text { Specific context } \\
\text { (1) Societal: sociodemographic } \\
\text { structures } \\
\text { (2) National: social welfare/social } \\
\text { security }\end{array}$} \\
\hline 2000s-2010s & US & & \\
\hline & Europe & $\begin{array}{l}\text { (1) Emergence of in-work poverty and } \\
\text { labour market segmentation (Smith } \\
\text { et al. 2008); } \\
\text { (2) Low pay (Cappellari 2002); } \\
\text { (3) Poverty in earned income (Pon- } \\
\text { thieux 2010) }\end{array}$ & $\begin{array}{l}\text { National: economic system (labour } \\
\text { market) }\end{array}$ \\
\hline \multirow[t]{4}{*}{ 2010s-2018 } & US & $\begin{array}{l}\text { (1) Low-income workers (Desmond } \\
\text { and Gershenson 2016); at the bottom } \\
\text { of the income distribution (Thiede } \\
\text { et al. 2015); } \\
\text { (2) Working, uninsured adults (Nolan } \\
\text { and Christie 2017); } \\
\text { (3) Working hard, working poor; a } \\
\text { global journal (Fields 2012); } \\
\text { (4) A booming demographic (Wicks- } \\
\text { Lim 2012) }\end{array}$ & $\begin{array}{l}\text { Societal: social protection system } \\
\text { (housing insecure and employment, } \\
\text { healthcare programme) }\end{array}$ \\
\hline & Europe & $\begin{array}{l}\text { (1) Re-emergence of working poor } \\
\text { phenomenon in Western Europe } \\
\text { (Pradella 2015); Widespread phenom- } \\
\text { enon, "hybrid" nature (Gautié and } \\
\text { Ponthieux 2016); a "post-industrial" } \\
\text { phenomenon (Marx and Nolan 2012); } \\
\text { a pan-European phenomenon (Marx } \\
\text { et al. 2012); } \\
\text { (2) Low-wage jobs with poor working } \\
\text { conditions and career opportunities } \\
\text { (Ilsøe 2016) }\end{array}$ & $\begin{array}{l}\text { (1) Global: international political } \\
\text { economy (IPE) perspective. Cross- } \\
\text { national perspective } \\
\text { (2) National: economic sectors } \\
\text { (low-wage service workers); social } \\
\text { protection system }\end{array}$ \\
\hline & $\begin{array}{l}\text { Colombia } \\
\text { Brazil }\end{array}$ & $\begin{array}{l}\text { Most vulnerable workers (Porras 2015); } \\
\text { Disadvantaged economic classes } \\
\text { (Escosteguy and Coutinho 2017) }\end{array}$ & Societal: socioeconomic inequality \\
\hline & $\begin{array}{l}\text { Asia (Hong Kong, } \\
\text { China) }\end{array}$ & $\begin{array}{l}\text { An important category of poverty; } \\
\text { low-paid work (Cheung and Chou } \\
\text { 2016) }\end{array}$ & Societal: socioeconomic context \\
\hline
\end{tabular}

social protection system (e.g., social services, care provisions, work and family policies, income support policies, and social insurance). Meanwhile, there is wide agreement that social welfare is a crucial factor affecting workers' well-being. For example, during the federal welfare-to-work reforms in the 1990s, American society suffered increasing numbers of working poor (Duncan et al. 2007). (3) Located in the lower classes in the economic hierarchy. The working poor are invisible, i.e., hidden in the lowest stratum of economic attainment, namely disadvantaged economic classes, even while the economy grows (Escosteguy and Coutinho 2017). (4) The fourth perspective involves the emergence of in-work poverty and labor market segmentation (Smith et al. 2008). Among segregated occupations, the majority of low-wage workers are employed in retail or restaurants, low-skilled service jobs become a key factor impacting poor conditions for workers in the Western world (Ilsøe 2016). Accordingly, research on working poor issues has transformed from a single analysis level to a multi-context analysis based on an international comparative perspective. 
From the original "male family head" to further calling on respecting individual perspectives. There have been attempts to identify the working poor from the original malehead household perspective to the individual level. Public debates have defined the working poor in relation to employed individuals who live in households with low household income levels. Early research in the 1970s primarily investigated working poverty among male family heads and traditionally regarded working poor as low-wage male labor (e.g., Greenberg and Kosters 1970; Tella 1971). We can trace the focus of the working poor concept on male heads in families. Due to the historical predominance of the male-breadwinner model in the labor market, males, as principal or sole earners, took primary responsibility for family economic support. In practice, boundaries between men's earnings and household income may have been blurred during that period, and observing males' earnings was the same as family income in most situations. Therefore, the early focus of the working poor on the household level became routine. This led to keywords of the working poor issue mostly linked to "low-income families" or "workingpoor household," which took the family context into research worldwide (for instance, the EU defined the risk of in-work poverty based on household median income).

The majority of research takes a household approach to the definition and measurement of the working poor. However, is poverty a household concept? The use of the household dimension is based on the assumption of equal sharing of resources among all family members, while it lacks strong justification because intrahousehold resource allocation itself is subjective and different without equal standard references. In fact, individuals' issues, especially women's economic vulnerability and dependency, are ignored; by using household income, the rate of women's in-work poverty is underestimated (Meulders and O'Dorchai 2014). It seems that the individual economic situation of women has never been abstracted from the household level. In addition, Moser and Young (1981), along with others such as Willen (1988), argued that the devaluation of women's unpaid housework had become both a social and political factor impacting professional women's lower labor power since the 1980s. The unfree choice of optionally assuming family responsibilities leads to women's high dependency on the family care obligation (e.g., more constrained by children or elders); as Willen (1988) described women's situation in the public sphere in early modern England, disparity family responsibilities meant that women frequently could only work part-time and low-paid, and they frequently predominated among the poor. Thus, "flexible" work becomes a keyword to understand the working poor phenomenon in the context of women (De Wolff 2000), such as when and why women work in flexible work. We can also see that in gender employment segregation, women who head households tend to remain in low-paid or less-skilled jobs, such as female-dominated service, sales, and factory occupations (Stellman 1988; Shiu 1989). Therefore, the capability and qualification of entering the labor market, pay, and career promotion are never equal between men and women. This probably explains why it is indispensable to explore women's situations among the working poor on the individual level.

Recent studies have defined in-work poverty based on individual income, which attempts to emphasize the female working poor (e.g., Ponthieux 2010; Meulders and O'orchai 2014; Karagiannaki and Platt 2015). Although earlier scholars tried to draw out a profile of female poverty at the regional level, Gulati (1981) conducted the 
study based on five poor working women in Kerala, India. However, the definition and measurement of the working poor (at the household or individual level) has been widely debated for several decades without consensus. From an individual perspective, the specific methods and theories of the female working poor issue have been in a "gray zone" until today. We agree with Ponthieux's view that "the existing EU indicator of in-work poverty needs to be complemented with an individual-based indicator of 'poverty in earned income,' where people earn less after tax than the amount required to reach the poverty threshold for a single person" (Ponthieux 2010: 29). Branching off from this point, further studies must be conducted from the individual perspective in research on female in-work poverty.

\section{The historical stages of in-work poverty research}

The research on the IWP phenomenon generally involves two large periods: the USoriented period (1970s-2000s) and the international diffusion period (the 2000s to the present). In the first period, IWP captured public attention primarily in the US and then in Canada and Australia. The first literature on the working poor entitled "The working poor" was published by the University of Michigan in 1965 (Wachtel 1965). In the second period, this new poverty issue in employment raised political and academic concerns in Europe. The field of in-work poverty (working poor) research has been in evident growth over the last two decades (Fig. 1).

\section{The United States-oriented period (1970s-2000s)}

\section{Working poor rising in the US}

Academic debates on in-work poverty began in the decade from 1965 to 1975, when a body of in-work poverty research could be categorized as the literature on poor working families in the US. The studies in this phase mainly responded to the following question:

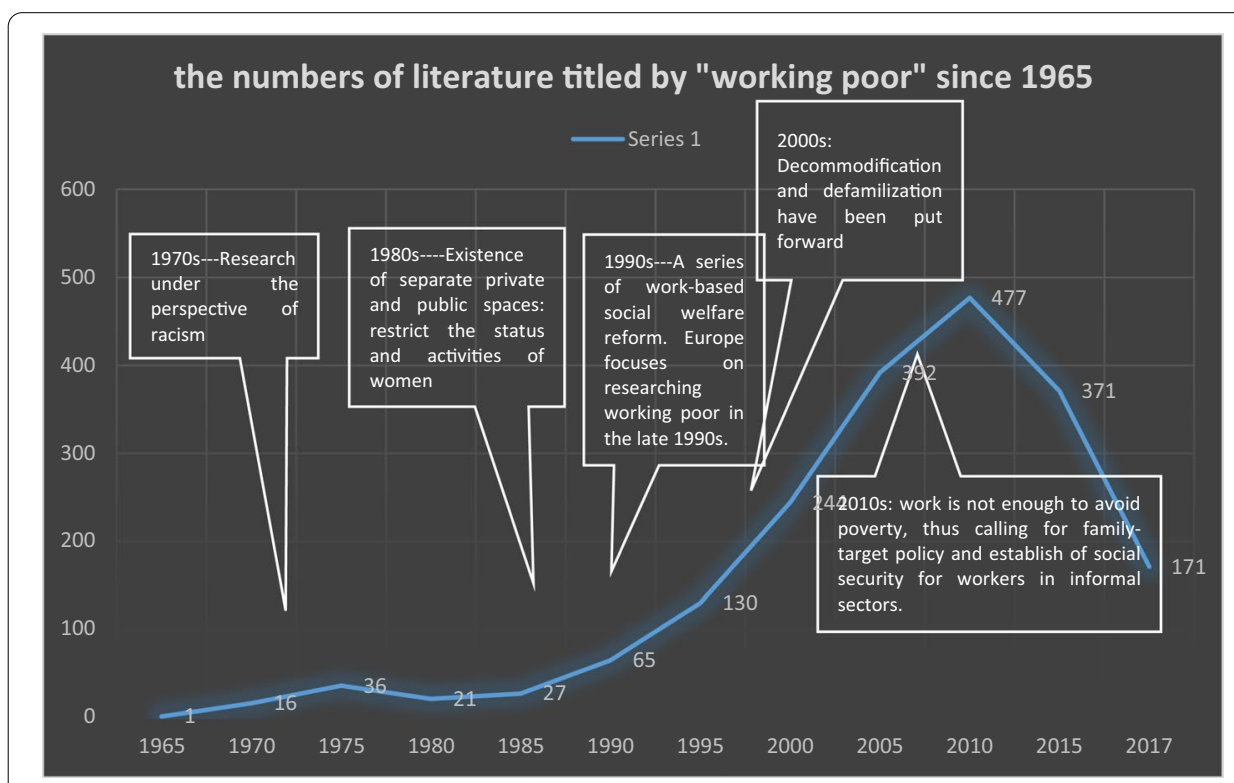

Fig. 1 Working poor research in literature 
what is in-work poverty? It was first identified in the US as individuals who had jobs but were, nevertheless, poor. The Office of Economic Opportunity (US) launched an empirical analysis of the effects of alternative income maintenance programs; in this research, "working poor" was officially defined in the US as households headed by married men less than 62 years old in families whose income did not exceed \$15,000 in 1966 (Greenberg and Kosters 1970).

Much of the in-work poverty research in this stage was linked to wage theory, examining anti-poverty strategies, particularly for the working poor. The early working poor phenomenon has already shown that poverty exists among the working population, in full-time workers, and particularly in low-paid sectors (Miller 1970; Wachtel and Betsey 1972; Bluestone et al. 1973; Jacobson 1975; Van Til 1975; Abbott 1980). Initial studies identified the working poor as low paid workers and used wages as a primary economic indicator to measure and target certain populations in surveys (Greenberg and Kosters 1970; Shea and Richard 1971; Bluestone et al. 1973; Haveman et al. 1973; Saltzman and Kidder 1974; Van Til 1975). Additionally, there was a growing body of evidence in the 1970s that income-targeted policies in the US were put forward directly to avoid the risk of poverty among working people.

There were two typical social programs to help reduce the number of working poor; one was the alternative income maintenance program that paid a subsidy to working low-income families or allowed negative tax rates on earnings, primarily launched by the Office of Economic Opportunity (US). For example, the Nixon Family Assistance Program incorporated a negative income tax provision and developed the Family Assistance Plan-Food Stamp Program (FAP-FSP) (Greenberg and Kosters 1970; Miller 1970; Greenberg 1971; Tella 1971; Haveman et al. 1973). The second was to raise minimum-wage gains by directly stressing wages to help the working poor (Keyserling 1966; Bluestone et al. 1973; Jacobson 1975). Nevertheless, the above two programs were not always effective strategies for avoiding poverty among working people. As Greenberg and Kosters (1970) argued, first, such efforts were probably offset by the purchase of increased leisure and subsidies, which reduced people's work intensity and work efforts to some extent; second, raising minimum-wage earnings also caused the substitution effect that employers may reduce labor supply, thus transforming more of the working poor into the unemployed poor.

From 1965 to 1975 is the initial stage in which researchers started to be particularly concerned about the phenomenon of poverty among working people, namely, the working poor. The early focus was on the relationship between poverty and wages in the labor market. In-work poverty research in this stage mainly focused on wage theory to find and examine anti-poverty strategies, particularly for the working poor. Although political debates have paid attention to this kind of poverty since the late 1960s, due to limited experience with mapping and targeting, working poverty was still ignored compared to traditional types of poverty (e.g., unemployment, disability, and homelessness) (Duggan 1969). Many scholars then addressed that the government was trying to create jobs without good results and that relevant policies such as skills training and education were operated for all poor people, which did not necessarily make a difference for the working poor. 


\section{Questions-oriented working poor research}

From 1976 to 1990, in-work poverty research entered an expanding research stage. This stage became a question-oriented one, with a clear problem consciousness, which mainly sought to answer two questions: what is the profile of the working poor, and what are the main reasons that lead to working poverty?

For the first question, the studies in this stage still widely considered that the working poor phenomenon was a problem exclusive to the US. It was an American contradiction that, on the one hand, increasing numbers of people who worked remained poor and suffered in the labor market, while on the other hand, the viewpoint that jobs were protection from poverty was still common in political anti-poverty strategies (Kachel 1988). In this context, most researchers lifted the veil of poverty, highlighting that poverty was not limited to unemployed people. They discovered that many people defined as poor were wage earners (Buchbinder 1983; Klein and Rones 1989). Meanwhile, related problems of the working poor have also been explored. For example, many workers commonly lack access to necessary social security, including mental health facilities and services, childcare for low-income working families, and unemployment insurance (Baskin 1982; McMurray and Kazanjian 1982; Smith 1985).

Among relevant research, the topic of the relationship between the informal sector and working poverty has been researched since the 1980s, with a particular interest in women. Meanwhile, a large body of literature emphasized that the female working poor quickly grew in the labor market due to economic, demographic, and cultural factors. This could be regarded as a milestone. Women's unpaid housework was undervalued in private spaces, which followed them into public economic activities; most women tended to be employed in informal sectors since women's unpaid housework lowers the cost of the reproduction of labor power (Moser and Young 1981). In this sense, women suffered more than men both in households and in the labor market. For instance, single female heads with children have the highest poverty rates among families with workers (Klein and Rones 1989).

Moreover, as Moser and Young (1981) pointed out in the article "Women of the working poor", the simple economistic explanation for the growing tendency of women's overrepresentation in informal jobs is inadequate. When the topic of the working poor has been researched from a gender perspective, it becomes a multifaceted problem, i.e., a confused mix of work, family, and poverty. In-work poverty is not only a problem in economic fields but also the main issue in the private sphere of the family, and espeically the tension given the multiple roles in both spaces in relation to constraints by local political authority and traditional cultures.

Some women were regarded as urban working poor in the 1980s because that is a historical period in most developed countries; large numbers of women had a strong interest in participating in economic activities, and most of them were employed in unskilled, part-time, or low-paid sectors. For instance, an analysis conducted by the US Census in 1980 revealed that a sizeable percentage of adult females employed full time (working more than 2080 hours in 1979) worked in female-dominated service, sales, and factory occupations, while they had family incomes that placed them in poverty or the impoverishment status (Stellman 1988). A number of scholars have drawn the profile of the female working poor under the construction of the labor 
market, and the poor working conditions of women at this stage demonstrated the big efforts made to gain the right to employment. Although social policies were targeting the poor, the female working poor were not given enough attention, and their conditions remained unimproved.

The second question that concerned scholars was: what are the main causes of poverty? In the 1980s, public debates (mainly in the US) tried to answer the following question: "Can any American who is willing to work hard make a decent living?" (Murray, 1987: 3). Before the 1970s, the consensus answer among policy-makers was always "yes". Since the 1970s, especially after the 1980s, the answer shifted to "no" because poverty had "reupdated", and in-work poverty could no longer be ignored. Several factors could have contributed to this kind of poverty. A low level of work status is a major factor, combining low income and low work intensity. To "fulfill the promise", some scholars proposed policy recommendations to increase the income of the working poor (Hepworth 1982; Shapiro and Greenstein 1990; Shiang 1990).

However, some studies argue that there is no causal relationship between low labor attachment and the working poor. Traditionally, people believe that poor people were poor because of laziness and low work intensity, i.e., they made little effort to seek advancement in their work. Notwithstanding, many working poor were neither ill nor disabled and usually worked full time (Klein and Rones 1989; Shapiro 1989). Danziger and Gottschalk (1986) have demonstrated that most heads of low-income families have strong labor force attachment, but they are more likely to engage in low-paying and insecure employment.

The working poor is mainly characterized by low attachment to the labor market or directly affected by low pay only; they also face economic poverty due to multiple reasons (e.g., a wage too low for many family dependents). In addition, other scholars pointed out the close links between family relationships and the working poor (e.g., Klein and Rones 1989; Shiu 1989). Shiu (1989) established relationships between work and family structure in terms of policies for the working poor, addressing the need to develop a series of social programs to balance work and family. In short, research at this stage demonstrated that work and poverty could go together and that family structure also plays a significant role in explaining the inwork poverty issue.

\section{Two theoretical viewpoints and two dimensions}

Research on in-work poverty rapidly developed in the deepening stage (1991-2000), which provided various valuable references for us on this issue. Studies conducted during this stage are critical for linking two particular theoretical viewpoints and two analytical dimensions to this new poverty phenomenon.

Two theoretical viewpoints The understanding of in-work poverty made significant progress in this stage. Not only was absolute or relative poverty classified, but the research on the working poor was also closely and deeply linked with two theoretical perspectives: social classification and social risk.

First, the working poor has been a focus of research in middle-level theory (e.g., social stratification, classification in the occupational hierarchy). Many developed 
countries, such as the US, have entered situations of low unemployment, rising mean family income, increasing wage inequality, and persistent poor work since the late 1990s (Craypo and Cormier 2000). Against this background, some scholars have suggested that the working poor were poor because they chose to work too few hours (Schiller 1994; Murray 1987) or because the labor market failed to provide them with adequate income and decent, full-time jobs (Marlene Kim 1998). Although policy-makers believed that if one works hard, one should not be poor, most working poor were still poor even if they worked hard and in full-time positions (already mentioned in the expanding stage). Then, the question of "why are the poor still poor even if they work full time?" was put forward. As anyone who works full time throughout the year can still be poor, in-work poverty is no longer a property only of part-time jobs (Bane and Ellwood 1991; Puente 1997).

In contrast, poverty varies according to occupations; it seems that, increasingly, jobs exist which tend to be in low-paid service occupations and industries, absorbing people into the precarious part of the labor market. A seminal work on this phase is Kim's (1998) article, “The working poor: lousy jobs or lazy workers?" which explores the relationship between work and poverty. In-work poverty research on middle-level theory in this stage involved labor market segmentation theory and social stratification, particularly in the occupational hierarchy (Seccombe and Amey 1995; Cormier and Craypo 2000). One important research finding asked, "Why still poor?" Having a job no longer ensures that a worker will avoid poverty because the market restructuring associated with economic growth appears to be creating both low-wage jobs and the working poor. Building on this view, Cormier and Craypo (2000) focused on hierarchical job structures to explain that the working poor existed and increased mainly because of the interaction of devalued work and the wide wage dispersion among job classifications. Moreover, he also looked at occupations: the basic manufacturing sectors were secured with relatively high wages and good benefits, and they were valued as men's work because of such occupational characteristics.

In contrast, some jobs in light industry manufacturing or services, among which more women were employed, were less valued. This was the truth of the working situation at the beginning of the post-World War II period. Currently, such job classification remains a feature of the job hierarchy and leads to inequality in the distribution of resources (e.g., income, time, job networks.). The "junk job" (low income, low skilled) is more common than ever. As such, jobs that are dominated by women (such as serving, cleaning, cooking, household, and office management) are devalued, with low wages, low status, and a high risk of (female) in-work poverty (Noponen 1992; Tickamyer 1992).

Second, some analysts have proposed linking "working poverty" to the concept of "risk"; they have underlined that the working poor with low incomes is at greater risk of sliding into a vulnerable economic situation when confronting divorce, a major illness, or any accident (Belcher 1994). Additionally, they have established the existence of a three-strike status of the characteristics related to in-work poverty: (1) low-wage work, (2) involuntary part-time job, and (3) temporary unemployment. On this basis, all empirical analyses using social risk theory have suggested that, due to the nature of risk, the social security system of most industrial societies cannot cover in-work 
poverty. For example, Thebault (1992) showed that health care access for the working poor is quite limited. Moreover, risk classification was generally used to design social programs that intend to protect people located in disadvantaged positions in society, and the social risk of the working poor sliding into poverty is often underestimated compared to unemployed people. In the article "Some preliminary thoughts on the deregulation of insurance to advantage the working poor," Hylton (1996) discussed the important role that various forms of social insurance play in the compensation of low-income employees. He evaluated current social protections (welfare programs such as disability and health insurance) and concluded that large numbers of lowincome workers often had limited access to health insurance (Hylton 1996). Additionally, some research continued to examine the impact of the early stage of welfare reform on poor working families. Kim and Mergoupis (1997) pointed out that many working poor who qualify for welfare benefits fail to receive assistance.

Two dimensions In this stage, two analytic dimensions have been significantly developed in relevant research; the household dimension was used for the first time in an ecological system model. The gender dimension has continued to be addressed and utilized in political decision-making.

Some researchers have used the theory of ecological systems to explore the situation of the working poor in the household dimension, holding that families in contemporary society are systems that usually interact with more powerful ones in their environment. The research emphasized that families are heavily affected by the complex social, economic, and political systems in which they are embedded (Chilman 1991). On this basis, some programs related to family well-being have been commonly recommended at the policy level since then. In addition, some family policies or tax policy initiatives have been put forward, such as increasing the resources of low-income workers through the "income-transfer" earned income tax credit program (EITC), raising the minimum wage, increasing public funding for childcare facilities, and making food stamp access easier. We found that most of these social programs mainly target people tied to work; thus, we called them "pro-work" or work-based social programs. For example, Scholz (1993) documented the EITC in the US, a program launched especially for poor working families in 1984. By redistributing resources from rich to poor households, the EITC directly targeted low-income families and increased the fairness of the tax system to some extent. He also noted that the EITC is closely related to employment status. Such policies have been enthusiastically discussed and evaluated during this period.

Moreover, relevant studies have also drawn portraits of the single working parent with children at higher risk of poverty in the US, Canada, and the UK. Their poor status is affected not only by work characteristics but also by the size of the family and by welfare-to-work reform (Kossek et al. 1997). Therefore, working poverty is linked with both family and work, and welfare is an efficient way to balance such problems in public and private spaces. Simply working hard is not enough to keep a family out of poverty, and welfare benefits are crucial to balance economic activities and domestic labor. Indeed, a series of government welfare actions and policies have reduced poverty to some degree, 
especially for single working people and female workers, by raising the minimum wage and the EITC.

The second type of literature began to focus on in-work poverty and who experiences it. In this literature, the gender dimension of IWP is revealed. For example, the US Bureau of the Census reported that over 8 million working people remained poor in 1987, which increased to 10.4 million in 1993. Against this background, scholars positively and dedicatedly explored who has a greater possibility of being poor. They identified farmworkers in the US (Griffith and Kissam 1995), Asian and Pacific Islander Americans, immigrant women in the US (Weitzman \& Berry, 1992), women working in part-time jobs ( $40 \%$ of female heads of low-income families worked in part-time jobs in 1987 (Chilman 1991)), or even female workers in informal sectors in Zimbabwe (Gibbon 1995). Since then, gender inequality has been appropriately integrated into poverty research. Many women employed in informal sectors are poor, e.g., playing reproductive roles for housework and childcaring. They are closely tied to family welfare and shoulder more responsibility than men.

In approximately 2000, the feminist analysis of working poor women was developed. Figart and Lapidus (1995) conducted a gender analysis of US labor market policies for the working poor. Riphenburg (1996) studied female informal sector workers in Zimbabwe, studying their working conditions and health issues against economic structural adjustment. An important poverty debate about "the feminization of poverty" has been advanced (Pearce 1978), in which there are mainly two viewpoints: the collision of multiple roles and the disadvantaged position in social structures.

First, according to the International Labor Organization (ILO), women in the workplace face inequalities in hiring, promotion standards, and access to training and retraining. Additionally, in the family field, even women in higher-level jobs in developing countries spend 31-42 h per week in unpaid domestic activities (International, L.O.I. 1996). Society shapes multiple roles for women, as employees, mothers, daughters, and family providers, and sometimes such roles are constrained in both public and private spaces if the state or employer does not provide specific policies or services to help balance them.

Second, certain studies have stressed the appearance of women-focused trends in the labor market, family structure, occupational segregation, and welfare systems that tend to push women into poverty. De Wolff (2000) observed poor working women in Canada, finding that facing both globalization and flexibility, poverty impacts women more than men in labor markets. Throughout the decade, government programs have contributed to the creation of a more "flexible" labor force and the feminization of flexible jobs and income discrimination are critical components in the persistence of poverty among young women and immigrant women (De Wolff 2000). Moreover, Gilbert (2000) researched working poor women's survival strategies and found that institutionalized women and racists in the housing and labor market affect how women fulfill their multiple roles. In a gender dimension, research on the female working poor must pay attention to public and private spaces to understand how these two spheres may play a role in in-work poverty. 


\section{The international diffusion period (the 2000s to the present)} Working poor rising worldwide

Before the 1990s, the "working poor" was regarded as a domestic phenomenon, especially in the US and Canada. Europe became interested in studying such issues in the 1990s (OECD 2009; Eurofound 2010a). In 2003, "in-work poverty" became a new commonly agreed indicator at the EU level (Bardone and Guio 2005). By adopting a standard indicator of in-work poverty, according to the report from the European Statistical Office in 2005 (Eurostat), approximately 7\% of employed people in the EU-15 had an income that fell below the national poverty line, and they could thus be classified as the working poor. Since then, research on in-work poverty has been developed widely in Europe. For example, a book titled The working poor in Europe: employment, poverty, and globalization was published in 2008, which was the first book to observe the different faces of in-work poverty in the European regimes. Additionally, Henning Lohmann (2009) combined micro and macro-level perspectives to explore the working poor in 20 European countries. His research shows that both welfare state measures (welfare-towork measures) and labor market institutions (flexibilization of informal sectors) influence in-work poverty.

Studies show that a common trend of market reconstruction occurred during the same period in most countries in Europe, America, and Asia. Public debates concerning inwork poverty have expanded to more developing countries, and cross-national studies in a third-world setting have begun to emerge since the pioneering research of Majid (2001) and Sundaram and Tendulkar (2002). In Asia, Japan, India, and China have experienced the rapid development of informal employment since the 1990s. In China, state-owned enterprise reform began in the 1990s, and many workers were laid off and transferred their work into informal sectors. During almost the same period, India has faced the growing prominence of informal employment since the early 1980s (Remesh 2009). At the same time, nearly $8.8 \%$ of economically active men were considered poor in 2004, while $10.5 \%$ of women were found to be poor in Korea (Kim and Lee 2007). Against this background, since the 2000s, research on the working poor has expanded in Asia (e.g., Japan, Korea). For example, since 2006, the growth of the nonregulated employment rate has led to the reconstruction of the Japanese labor market, so that one-third of the total Japanese working population was employed as part-time workers, dispatch workers, and day laborers; in-work poverty has grown since then in Japan.

Research on in-work poverty has entered a new stage since the 2000s. The first books exclusively focusing on the working poor appeared in the early 2000s (Lagarenne and Legendre 2000; Strengmann-Kuhn 2002; Peña-Casas and Latta 2004). The main point is whether the existing welfare system (reform) efficiently targeted poverty among workers. This association is crucial for social policy because social security and relevant services are particularly important to get out of poverty. It is also a period during which largescale research, with ambitious enthusiasm, seriously reconsidered some assumptions about poverty and work. The "patron-client relations" of work to people were doubted, reexamined, and questioned. Why were individuals who held jobs still poor? The need to solve this puzzle led to the reconstruction stage. 


\section{Work is no longer enough to avoid poverty}

In the literature during this stage, we first find that public debates concerning in-work poverty have expanded to include developing countries and continue to reexamine the relationship between work and poverty by asking, "why do the working poor remain poor"?

Some research has drawn the picture of the working poor in developing countries; an article estimates that approximately 534 million people could be classified as working poor in developing countries in 1997, accounting for $25 \%$ of the employed labor force in developing countries (Majid 2001). Other researchers have focused on the impact of globalization and the informal economy on in-work poverty. Under the trend of economic globalization, there is an increase in people who work in the informal economy and earn low wages. An important question has been put forward about whether increasing the incentive of employment can effectively reduce poverty. Some scholars, such as Strengmann-Kuhn (2002), have pointed out that governments should encourage nonactive people of working age to be employed; primarily for women, work subsidies are necessary to help part-time workers and low-income workers avoid poverty, and this positive effect is stronger in urban than rural areas. Berger and Harasty (2002) noted that because work is often the only source of income for the poor, poverty directly relates to employment, and reducing the unemployment rate and low-income/low-skilled jobs are efficient ways to erase poverty.

Nevertheless, some other scholars have pointed out two problems. First, the problem of the working poor concerns not only workers themselves but also their family members. Therefore, to guarantee that employees will not be poor, it is necessary to take political action for employees and implement household-related policies. For instance, childcare has become a major problem for the working poor in China, where children usually do not receive a family allowance. Much research has addressed that children in low-income families experience far more barriers to care than other children, such as a lack of health resources and public assistance. Therefore, workers' wages are often insufficient to avoid poverty, especially for single working mothers or working parents with many children. Increasing wages is not the only way to avoid poverty, and family policies have become an option to cope with the problem.

Second, many policies push families from welfare to work and yet create other conflicts; for instance, some multiple and incompatible policies impact low-income families and place them in the difficult position of choosing between economic stability or mobility and children's educational performance. There is an agreement that welfare reform has proposed many policies to promote employment and reduce unemployment rates to eliminate absolute poverty while potentially causing the formation of a larger group of working poor people.

The complexity and increased audits of income-based subsides, for instance, increase the difficulty for the target families to access. Lipman (2003) pointed out that the complexity of the EITC rules and compliance requirements create a profitable business niche, in which the working poor are paying for professional tax assistance. It leads to a diversion of anti-poverty benefits to the commercial tax preparers, and in this way, these working poor are paying for the hole of the anti-poverty programs. At this stage, many welfare reforms have been tested and discussed. There have been three main strategies: 
(1) income-based subsidies (e.g., EITC), (2) skill-based services (e.g., employment training in the community), and (3) family allowances (e.g., family care services). Welfare-towork measures are recommended and widely adopted; they are based on the principle that work is the path out of poverty. For example, the Earned Income Tax Credit is one of the most useful anti-poverty programs in the US and has operated for decades. Interestingly, poor people receive such subsidies only if they have work and pay taxes, but the subsidy is used to pay back overdue bills. The EITC as an income-transfer program was designed to use for saving toward a car, a house, medical needs, or education.

Furthermore, the strategy of increasing the minimum wage has been questioned; some researchers suggest that raising the federal minimum wage continues to be an inadequate way to help the working poor. Therefore, Andrew Jackson questioned, "are wage supplements the answer to the problems of the working poor"? In this sense, large-scale research has demonstrated that employment can lift households out of poverty, but it can also increase the number of poor workers. Income-based subsidies have a limited effect on in-work poverty. Therefore, some other researchers have suggested strengthening related policies to increase the education and skills of low-wage workers. This is the second strategy to replace the first one.

Moreover, as market reconstruction in many countries faces the trend of the predominance of informal sectors, an increasing number of workers are employed in jobs classified as flexible and uninsured. Thus, providing social security to workers in informal sectors is also a useful approach. Scholars have suggested two main channels to help the working poor: one is family-targeted policies (e.g., direct family cash benefits, the parent leaves scheme, and the provision of childcare services). For example, the UK has experienced an obvious reduction in the family child poverty rate through adopting family-target policies through direct benefit transfers, family leaves, and family-based allowances. The other is to enhance the social security of informal employees. Henning Lohmann (2006) explored the influence of welfare and labor market institutions on working poverty in Western Europe and found a strong connection between welfare state characteristics and household-related charactersitics (Lohmann 2006). The above two channels are all based on household support purposes because if people are well housed and their families are securely stable, they will focus more on their work and enjoy their lives. However, this leaves open the issue raised previously, i.e., a household-based conception of poverty is detrimental to women's independence.

\section{The relationship between in-work poverty, the labor market, and social security}

In-work poverty has revealed its close relationship to in-work status. Since the 2010s, a large body of literature has focused on answering the following question: what is the relationship between the working poor, the labor market, and social security?

There has been growing concern about the problem of in-work poverty since the outbreak of global economic crises (Marx and Nolan 2012; Marx et al. 2012). For example, in the UK, the 2007-2008 financial crisis affected the prospects for workers in a range of ways, in-work poverty being one of them (Richards and Sang 2018). Since most of the working poor who work full time or year-round do not avoid poverty (as we have mentioned before), it is helpful to explore the nature of work and its relation to poverty in depth by first observing how the poor are working. As Wicks-Lim (2012) noted 
that the working poor must be working hard, it is the "hard" norm that indeed inspires us to think about what makes them work hard or, put differently, to essentially reflect on workers' well-being behind the changes in the labor market and welfare. Since the 2010s, especially in the European debate, there have been large-scale studies that tend to explore the "hard" conditions among the working poor, in two aspects in particular:

First, the changes in jobs and the labor market and their relationship with the persistence of in-work poverty have been mainly examined. Below, we consider two fundamental trends in the labor market development that may affect the working poor.

(1) Flexibilization. Wim Van Lancker (2012) gave a precise definition of the increasingly precarious or flexible employment tendency, which refers to an employment relationship with a limited duration mostly occurring in nonstandard or temporary jobs and fixed-term contracts. A growing body of research has demonstrated that the number of workers in low-wage and nonregular jobs is significantly increasing in the labor market, while at the same time, in-work poverty is widely considered a phenomenon related to the growth of this kind of insecure employment in the service sector (Max and Nolan 2012). Under such a flexible tendency, the working poor is at "the bottom of the income distribution" and comprise a sizable segment of the workforce (Thiede et al. 2015). Previous studies have demonstrated that the trend of higher flexibility in the labor market has impacted the working poor unfavorably (Dafermos and Papatheodorou 2012; Sieverding 2012). In particular, Johannes Petry (2014) used the theory of decommodification to explain how the increased flexibility of the labor market creates poverty among the working population. Likewise, Fritsch and Verwiebe (2008) analyzed Germany, Australia, and Switzerland from a comparative perspective to discuss the relationship between labor market flexibilization and in-work poverty.

(2) Globalization and Individualism. Under the trends of globalization and individualism, the working poor has a high level of precarious risks, and social security indeed plays a pivotal role in preventing labor poverty. The existing research has already found that these trends cause and perpetuate poverty among the working population and their households, including the factors of family size, household status, widowhood, disability, low wages, and wage discrimination, especially in the case of female workers. For instance, research focusing on the cause of poverty generally finds that job quality is the primary factor in explaining IWP (Goerne 2011). Additionally, others have noted that there has been a substantial increase in divorce rates in Europe since the 1960s, with negative economic consequences for women and children as they suffer a higher risk of poverty (Meulders and O'Dorchai 2013). Based on this, it has been considered that social security needs to be reformed to cope with this precariousness.

Second, substantial literature reexamines the "hard" conditions among the working poor in the context of macrosocial processes; in other words, they address the relationship with social security.

It is often believed that social security is most effective if it proximately targets poverty among workers. Marx and Nolan (2012) argued that in-work poverty would be strongly tied to institutional settings, labor market structures, benefits systems, and the broader welfare state. Based on the widespread belief of in-work poverty as a problem of insufficient work effort or a lack of employment opportunities, the policy interventions that followed the work-based welfare reform since the late 1990s have 
closely linked individuals' well-being to work status (Thiede et al. 2015). As a result, an increase in work-related/income-based welfare programs to support working poor-minimum wage legislation, the EITC, family allowance, and other work supports-have been launched in many countries, and policies implemented in the US, $\mathrm{UK}$, and EU are discussed.

Nevertheless, the number of working poor seemingly grew during this reform. Previous studies have pointed out that during the past 20 years, some existing income support policies (e.g., belonging to welfare-to-work services) have failed in many countries at coping with the rising trend of poverty among workers (Mack 2014; Marchal et al. 2017). For example, although the minimum-wage setting has been commonly regarded as an income-based program to protect the core income standard for workers in many countries, minimum wage increases as an anti-poverty measure have been under intense criticism since the 2010s, as they are weakly connected to decreases in the working poor (Marx and Nolan 2012; Burkhauser 2014; Mack 2014). Mack (2014) examined the effects of the minimum wage on the American working poor from 1990 to 2011 and highlighted the limitations of its correlation. Elsewhere McKnight et al. (2016) explored the effectiveness of increases in the minimum wage to reduce poverty in today's European labor market. Marx and Nolan (2012) noted that even though the relatively high minimum wage setting can probably induce the increasingly working poor, if the minimum wage is not sufficiently high relative to the poverty threshold, a single breadwinner with dependent children may not be lifted from poverty. In addition, a high minimum wage may also potentially protect the solo breadwinner model and restrict the access of some workers with low skills/education, thus making it difficult to support low-income households with dependent children. In this sense, to some degree, establishing a low minimum wage is no longer enough to explain the phenomenon of in-work poverty, particularly for women as the sole earner or with low skill/education levels. Work is not always sufficient to avoid poverty; even working many hours and holding full-time, year-round employment is no longer a guarantee of escaping poverty (Boschmann 2011; McKnight et al. 2016).

There is a need to further understand the link between in-work poverty and two spaces: the informal employment sector and the family field. There is strong evidence that family-targeted policies and the social security of informal sectors have a positive effect on the working poor. Alonzo (2012) conducted fieldwork to observe the working poor's strategies to meet subsistence and gain knowledge of unmet needs. Alonzo found that family support and mutual help among family members are usually basic assistance methods and that family composition (family size and economic situation) is closely linked to their living and working conditions. Additionally, Desmond and Gershenson (2016) explored the role of housing and employment security in in-work poverty. They pointed out that promoting housing stability could promote employment stability among low-income workers, which, in turn, may efficiently help and support the working poor.

\section{Neglected women among the working poor}

Since the 2010s, an increasing number of scholars have realized that in-work poverty has become more prevalent; in particular, women have an increased likelihood of becoming 
working poor. For instance, Khosla highlighted women's situation among the working poor in Canada in 2011 and 2014. She found that, in most of the areas of Canada, the low-income economy produces in-work poverty with "feminized" and "racialized" characteristics, and even single mothers suffer worse among the working poor. Nevertheless, poverty among women workers in the labor market has received little attention in antipoverty strategies. Women in the in-work poverty research are overlooked and therefore not well understood, resulting in methodological and conceptual challenges.

First, there are methodological issues about the household-level indicator, which potentially lead to underestimating the poor working women. Since the 2000s, the working poor phenomenon has become a crucial political topic in the European debate. A new indicator-in-work poverty risk-was added to the Laeken indicators in 2003. Based on this index, the working poor has increased from 8.3\% in 2010 to $9.5 \%$ in 2016 in the EU28 (Eurostat 2016), and some comparative research on the working poor has been conducted in the European context. In most of the European literature, the definition of working poor is quite solid, as the majority of researchers define being poor on the basis of a relative poverty threshold (equivalized household income being under 50\% or $60 \%$ of the national median income), and working poor is commonly understood as being below the household income level.

However, the debate over adopting an economic indicator of the working poor based on household or individual levels started recently. In general, a single earner with dependent children suffers an increased risk of poverty (Rogers 1990; Eggebeen and Lichter 1991; Van Lancker 2012). In his European comparison, Wim Van Lancker (2012) demonstrated that workers living in a single-earner household with dependent children have an increased probability of living in poverty, whether in temporary or permanent employment. Moreover, he pointed out that women who work in temporary jobs have a lower poverty risk than their male counterparts because dual-earning households mainly protect women. Nevertheless, his work shows another risk factor for women: in facing migration, widowhood, separation, or divorce, women will lose such "advantages" as being the second earner and suffer more in employment. This point has been echoed by early research showing that women have higher poverty rates than men across all family types (Rogers 1990). Taking off from this view, some researchers, such as Ponthieux (2010), have suggested using the term of "poverty in earned income" or "economic poverty" based on individual income, thereby addressing the importance of measuring the female working poor. Because most household income situations may hide the real economic situation for women in the family, an individual income indicator is significant for discovering the female working poor, as it correctly reflects the real economic situation of female workers. Ponthieux (2010) used individual earned income to measure the working poor, finding that women are much more exposed to economic poverty than men compared to what most research in Europe found based on equivalized household income.

Second, the lack of a gender dimension may homogenize the social construction of in-work poverty. Since then, among the working poor, women have been increasingly focused on but are still far more limited. Crettaz (2014) pointed out that it is counterintuitive that differences between men and women are slight in in-work poverty. This is essential because large-scale research shows that women are more likely to be poor and 
disadvantaged in the labor market than men currently are (Crettaz 2014; Lohmann et al. 2017). Strier et al. (2016) used the gender dimension to examine working men's views of poverty in Israel and highlighted the gender differences in the social construction of in-work poverty. Therefore, the female working poor is a multifaceted problem with a highly poor possibility, different from men in terms of experiences, characteristics, and causes.

Due to gendered employment segregation and unequal household allocation, women are heavily overrepresented in low-value and unstable work; therefore, they have a higher possibility of entering unstable, uninsured, and more flexible occupations and thus have a higher risk of poverty in the labor market. In addition, in the existing national provisions, we find that it is difficult to target special groups with a minimum wage increase, such as single working mothers, as income is not the only thing needed, with childcare services seemingly more important. In these situations, many scholars emphasized adopting more gender-oriented policies for women and suggested the need for more research with gender dimensions to respond to the complexity of in-work poverty.

\section{Key trends in the in-work poverty research}

The literature concludes the timeline of in-work poverty studies, definitions, and central research questions (Figs. 1, 2, and 3). Based on this, there are six trends in the in-work poverty research that may inspire further research.

\section{Trend 1: Work is not enough to avoid poverty; thus, how will the working poor get by without social security?}

First, in terms of anti-poverty strategies, employment does not work. Of all the questions (see Fig. 3), the main issue is that employment is insufficient to avoid poverty. Kim (1998) argued that working harder (working more hours) is not a solution to poverty, and the working poor will not disappear by inducing a greater work effort. The phenomenon of the working poor itself is sufficient evidence to change people's point of view, from the traditional idea that "if one works hard, one should not be poor" to the challenging fact that "simply having a job does not end poverty." Employment is no longer the principal way to get out of poverty.

However, the social security settings in many countries have a limited impact on alleviating in-work poverty. Large-scale research has observed that social security does not adequately cover the number of working poor. Most working poor live in conditions where they lack related social resources and access to necessary social security, such as medical assistance, health services, and unemployment insurance. For instance, most low-income workers have quite a limited access to medical insurance; this is also true in China, where most low-wage workers cannot afford to pay an individual's share of insurance. Thus, the considerable research has described in negative terms the functioning of the existing social security systems in many countries (such as Canada and the US), which have proven to be weaker than often believed for helping the working poor, thereby missing their anti-poverty targets. 


\begin{tabular}{|c|c|c|}
\hline $1965-1970$ & working poor: housholds headed by married men & $\begin{array}{l}\text { 1965-1970: The absence of } \\
\text { married women in the sample }\end{array}$ \\
\hline \multicolumn{2}{|c|}{$\begin{array}{l}\text { - households headed by married men less than } 62 \text { years old in families whose incomes } \\
\text { did not exceed } \$ 15,000 \text { in } 1966 \text { (The Office of Economic Opportunity US, 1965) }\end{array}$} & $\begin{array}{l}\text { 1971-1975: Contains too few } \\
\text { female respondents in related } \\
\text { research }\end{array}$ \\
\hline 1971-1975 & working poor: under the perspective of racism & \\
\hline \multicolumn{3}{|c|}{ •minority workers in low-wage, low-skill jobs (Dennis P. Sobin,1973) } \\
\hline $1976-1980$ & $\begin{array}{l}\text { working poor:expand to some working groups when } \\
\text { facing big social changes }\end{array}$ & $\begin{array}{l}\text { 1981-1985: Milestone : } \\
\text { women of the working } \\
\text { nnnr cinrs } 1081\end{array}$ \\
\hline \multicolumn{2}{|c|}{$\begin{array}{l}\text { - low-income residents when facing land invasion (Dietz H A, 1977) } \\
\text { - academic families with a single income (Abbott W F, 1980) }\end{array}$} & $\begin{array}{l}\text { 1986-1990: Work, poverty } \\
\text { and women: correlation or } \\
\text { casual relationship? }\end{array}$ \\
\hline $1981-1985$ & women of the working poor & \\
\hline \multicolumn{3}{|c|}{ - most of poors are wage earners at least in Cnanada (Buchbinder H, Ross D, 1983) } \\
\hline $1986-1990$ & two questions need to be answered & \\
\hline \multicolumn{3}{|c|}{$\begin{array}{l}\text {-persons who are labour force participants but live in poor families (Klein B W,1989) } \\
\text {-working but poor (sar A,1987) }\end{array}$} \\
\hline 1991-1995 & two dimensions & \\
\hline \multicolumn{2}{|c|}{$\begin{array}{l}\text { - The farmworker, Asian and Pacific Islander Americans, immigrant women in US, } \\
\text { female women work in part-time job in US. }\end{array}$} & $\begin{array}{l}\text { Female working poor are } \\
\text { usually underrepresented }\end{array}$ \\
\hline \multicolumn{2}{|c|}{$\begin{array}{l}\text { - lower class as workers who earns current dollars are below cutoff which adjusted } \\
\text { overt time for inflation (Davis J C, Huston J H. 1991) }\end{array}$} & $\begin{array}{l}\text { as most researchers } \\
\text { adopting household }\end{array}$ \\
\hline \multicolumn{2}{|c|}{$\begin{array}{l}\text {-working poor are characteristic as low-income and at greater risk of sliding into } \\
\text { vulnerable economic relationship when confronting divorce, a major illness or any } \\
\text { accident. (Belcher } J \text { R. 1994) }\end{array}$} & income level. \\
\hline 1996-2005 & in-work poverty in housheold dimenison & \\
\hline \multicolumn{3}{|c|}{$\begin{array}{l}\text { - people whose income, even though they participate in paid work, is at or below the } \\
\text { minimum subsistence level. (Valkenburg B, 2000) }\end{array}$} \\
\hline \multicolumn{3}{|c|}{$\begin{array}{l}\text {-individuals who spend at least six months in the labour force, working or looking for work, } \\
\text { but whose household's standard of living is below the poverty level.(Lagarenne C, 2000) }\end{array}$} \\
\hline 2006-2015 & $\begin{array}{l}\text { a trend of market reconstruction: flexi-jobs or informal } \\
\text { sector orientation }\end{array}$ & \\
\hline \multicolumn{3}{|c|}{$\begin{array}{l}\text { - all full-time or part-time employees/self-employed workers aged 15-64 who live in a } \\
\text { household with an equivalised household disposable income below } 60 \% \text { of the median of } \\
\text { this income in the country (European Commission, 2013) }\end{array}$} \\
\hline \multicolumn{3}{|c|}{$\begin{array}{l}\text {-people who have jobs but were still suvriving under than US1.25 a day per person. } \\
(\text { (ILO,2013) }\end{array}$} \\
\hline ig. 2 The develop & nent of "working poor" definition in articles since 1965 & \\
\hline
\end{tabular}

\section{Trend 2: the lack of attention to working poor research in developing countries}

Second, the bulk of the literature on in-work poverty has come from developed countries; most research has originated in the US and then the EU, while there is insufficient attention to the issue in developing countries. As a new poverty issue among the employed population, in-work poverty belongs to the Paugam's conception 2017 of "disqualifying poverty", which refers to a high-risk status in which individuals can suffer sudden changes in daily life (Paugam 2017). In contrast to traditional forms of poverty, in-work poverty is derived from economic globalization in which poor status is closely related to the precarious work and instability trends in the market. Thus, it is very likely to be widespread in many societies in a global economy. This phenomenon affects society as a whole and enables us to keep an eye on its tendency to go beyond territorial boundaries. On this premise, as a very important member in the global economy, China is experiencing rapid changes in the market in which the issue of poverty has shown to 


1965-1970

share commonalities with other societies. That is, more people face an increasing burden of being disqualified in precarious situations. Nevertheless, research on the working poor in China is located at the margins of academic research.

\section{Trend 3: the trend of market reconstruction calls for family-targeted policies and assistance for the informal sector}

The literature attempts to identify the multiple faces of working poor issues, which have generally demanded multidimensional (i.e., gender, racism household dimension) policies.

In early research on the working poor in the 1960s, income played an important role in anti-poverty measures, and the minimum wage was considered an efficient method to help the working poor in the labor market. From the 1960s to 1980s, some nations (e.g., the US and Canada) adopted a series of income-related policies to cope with in-work poverty among workers, such as raising the minimum wage and the ETI. Even though they have been proposed as effective means to combat poverty in these countries, there is still doubt about whether the target of these measures is the working poor. Some scholars have found that simply raising the minimum wage has pushed some employers to hire many low-income workers. Additionally, the ETIC only targets low-income 
working families, and many low-income workers are not qualified for such programs. Some income-related policies such as the ETIC tie people to work closely and encourage poor people to work while keeping them in relatively low-wage jobs of poor quality. Particularly given the predominance of the informal sector in today's labor market, such income-related social programs are not targeting the working poor to some degree.

Following economic globalization and informatization since the 1990s, many countries have been experiencing market reconstruction; the old economic and social order is phasing out. A new invisible trend is occurring as the labor force shifts from formal sectors to more flexible informal sectors. Such changes in the labor market have a broad influence on workers and their living conditions; wages are no longer enough to avoid the risk of falling into poverty. Flex-jobs, or the informal sector-oriented trends of market reconstruction, call for family-targeted policies and social security for the informal sector to subsidize work-related policies (in work benefits). Therefore, the concern of family policy has been expanded. On the one hand, the future reformed social security system could explicitly provide programs aiming at family assistance in the household field. On the other hand, stable and safe working conditions are vital for workers and, hence, could be given prominence in informal sectors by establishing corresponding social security programs, especially for low-wage workers. Moreover, special programs (such as job training, childcare, and housing services) may be designed for single mothers and their children because they have remained invisible to government agencies for much of history (Fig. 4).

\section{Trend 4: women have been underrepresented in working poor research in the past}

The early research on the working poor in the 1970s mainly focused on targeting which working groups might have greater risks of being poor. From the racial perspective, large-scale research finds that minorities (such as black people in the US) are often employed in low-paid, low-skilled jobs and risk being poor than non-black citizens. Otherwise, some observers have claimed that graduate students initially enter the labor market and that migrant people are usually pushed into poverty. Particularly in Asia, according to the conference of international labor organization in the Asian region in 2006, approximately two-thirds of the working poor are women, and they have a higher possibility of losing a job. Briefly, low-income workers, migrant workers, and minorities are often observed in the literature, and the dimensions of race and education are

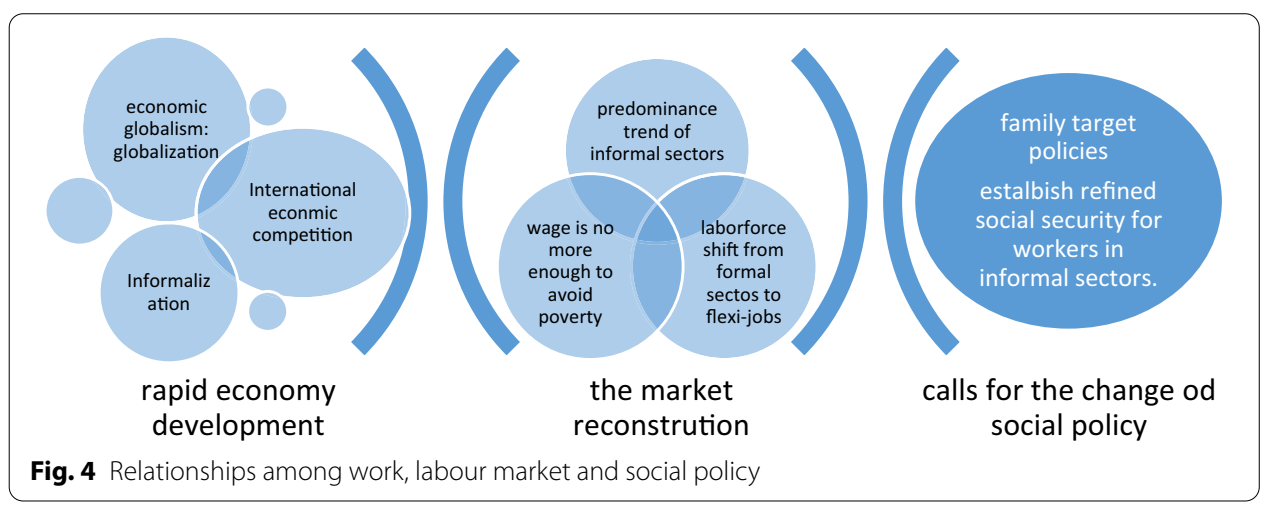


generally used in research on the working poor during the last 50 years. The literature neglects the gender dimension, however. For instance, male heads of families were usually the object of working poor research in the early 1970s, while females were often ignored in research designs. There were even few female research participants in these related analyses.

While sociologists such as those mentioned above have not particularly focused on the issue of gendered in-work poverty, much of their work has illuminated some aspects of the female working poor that help develop a gender analysis of this issue. Many women currently work as men in economic activities, while most of them are employed in flexible jobs. Many types of research have highlighted that women are often segregated into low-wage and low-growth potential job markets. Some research has emphasized that female workers as single earners with children often have a higher risk of poverty if they lose a job, and their needs and family care situation would force them to choose fulltime work. This work has received little attention, and women are usually underrepresented in the research on working poor people, which mostly adopts household income levels. Additionally, relatively little has been written on the impact of welfare reform on women who work in low-wage jobs.

\section{Trend 5: low-wage workers are often targeted in research on working poor}

Large-scale research has examined the problems faced by low-wage workers and their families since the early 1970s. Moreover, a growing literature has emphasized that labor market institutions have played a fundamental role in explaining the extent of low-wage work since the 2000s. Since then, low-wage workers have often been targeted in research on working poor; they are employed in the informal sector, have flexible jobs, and are low paid, leading to a higher risk of poverty. Otherwise, the vast majority of low-wage workers are homeworkers, urban informal sector workers, casual/temporary workers, construction workers employed by small contractors, and workers in the retail trade. For various reasons, women tend to be employed in the above sectors and are more likely to be employed in bad jobs in the labor market hierarchy, uninsured and uncovered by social security, and thus denied the protections they very much need. Therefore, the low wage is still a strong theme in in-work poverty, particularly for women, which needs to be considered within the welfare reform context in both developed and developing countries.

\section{Trend 6: the factors impacting in-work poverty and how to affect such social issues have} not yet been explored in detail

The working and living conditions of the working poor have been widely described, and much of the literature has investigated their experience of being poor, their housing situation, and lack of employment security. Meanwhile, the relations among the labor market, welfare, and working poor have been discussed. Nevertheless, little attention has been given to exploring the impact of the social protection system and labor market conditions on certain groups of working poor (e.g., low-wage workers and women). In the relevant literature, it is clear that most of the working poor are low-income workers, and the close link between low wages and poverty is mainly reflected in the female working poor. It is a problem of employment itself, and it is a problem of the social welfare 
system, which already has revealed its inadaptability to cover new social risks and needs and is failing in its promise of providing protection and security. Based on this, the factors that affect this particular social issue and how to affect it step by step in the international context need to be explored in further detail.

\section{Gendered in-work poverty under individualism and globalization}

In 1995, the Fourth United Nations World Conference on Women first addressed the importance of the gender dimension in poverty issues and identified "women in poverty" as the primary concern in the Beijing platform for action (BPFC). This review finds that, regardless of the methodology employed, the literature concludes that poor individuals are not distributed randomly in the population. Women seem to suffer more disadvantages than men in poverty issues due to structural and cultural causes. Moreover, the social protection system and labor market policy play a crucial role in pushing women into a high risk of poverty.

The term "feminization of poverty" has been widely recognized and adopted at the European level since the 2000s. In 2007, the Parliamentary Assembly of the Council of Europe pointed out that women have a higher incidence of poverty than men and that poverty among women is continually increasing and more severe (Stratigaki 2015). Since then, combating women's poverty has remained a high priority on the European policy agenda in terms of anti-poverty initiatives and promoting a social inclusion framework; the Europe 2020 Strategy correlates the reduction of women's poverty to the objective of inclusive growth, including the Manual for Gender Mainstreaming Social Inclusion and Social Protection Policies (2008), the European Platform against Poverty and Social Exclusion (2010), the Integrated Guidelines of the EU 2020 (2010), the Strategy for Equality between Women and Men 2010-2015 (2010), and the Evaluation of the Strategy for Equality between Women and Men 2010-2015 (2014). Nevertheless, the condition of women is not optimistic. As the evaluation of the European Social Fund for the 2007-2013 period has shown, the political actions on reducing female poverty are far from the top of the Member States' policy agendas (GHK and Fondazione 2011).

\section{In-work poverty under individualism and a globalized world}

We live in a world in which societies are at risk, with increasingly flexible, precarious trends in the main areas of social life (Beck 2004, 2014; Castel 2011). That being the case, in-work poverty is being approached as a complex combination of the poverty issue and the growing social risks in the labor market, followed by individualism and globalization. Globalization and modernization are never the processes of homogenization, which has produced even greater complexity in the flexibility and precariousness of the types of employment, which leaves people to face the risks of the life cycle in an individualized way.

On the one hand, under the globalization of economic development, market cooperation, and political dialogs, poverty has become a common risk that everyone may face today. Even though the majority of us are protected and regulated in social life or "routine" (such as family network, work-life, and welfare system), in-work poverty has developed, expanded, and transformed its meanings deeply in society; that is, as a usual and common stable life status, work cannot secure people's living standards anymore. 
In-work poverty is closely linked to the trend of individualism; it has become a global risk that is no longer centered on specific social groups. On the other hand, poverty impacts specific working groups, which may differ in their characteristics according to the different national, political, and historical contexts and, of course, gender. For instance, European societies have faced a series of structural changes (e.g., increased flexibility and precariousness of work, erosion of the male breadwinner model, deconstruction of gender ideology, and persistent high shares of women in low-skilled jobs) during recent decades, which challenge traditional social security or protection networks. Recent economic crises amplified individualism and globalism have caused many people to earn their living in more precarious conditions, particularly female workers (Beck 2014).

In Europe, Peña-Casas and Ghailani pointed out that the current in-work poverty indicator does not adequately reflect working women's increased risk of poverty (Peña-Casas and Ghailani, 2011). Additionally, gender topics have rarely been discussed in China, even if research on poverty is closely related to social policy, family networks, and people's interactions. Yiyin (2012) concluded that the "person" (ren 人) is not the independent individual in Chinese cultural construction; it involves a reciprocal linkage with other people. The structure of Chinese society seems to be that of "knitting a sweater" in which individuals are knitted together to construct different "patterns," and an individual's self-value/recognition is formed/constructed by belonging to a pattern (family, work unit, and public organization). In a way, it is similar to what we understand as "social inclusion" in the European context, while the difference is that the individual has been hidden in the collective forms of the Chinese social structure. In other words, the basic social unit is the family rather than the individual, whereby a person can be principally protected by family, work units, or other social organizations. However, as we will see, following globalization and urbanization, some people have fallen out of former networks. Hence, poverty is increasingly emerging in an individual way in China today.

Individualism implies more freedom and opportunities for women to enter into public activities, such as economic construction and political dialog. It also means reconstructing social status, gender roles, household compositions, and precarious employment (such as the workplace, labor contract, and working time). Thus, the tendency of individualization may occur in the marital area of the labor market, in which women have been disadvantaged. The number of women who become single mothers who enter the labor market with flexible and unstable working conditions increases. In addition, the capitalism shows its individual orientation in the labor market, that is, the commodification of a person's time and energy, and workers' personal responsibility to secure their own employment (Callero 2017). It follows that individualism has realized the transformation of people's status from being a "receiver of welfare" to a "self-responsible person."

Nevertheless, the existing social security based on traditional social structures (e.g., big family, dual-parent family, and male-breadwinner model) would not protect all groups today; furthermore, it is becoming increasingly difficult for individuals to support care for themselves. Therefore, poverty may develop and manifest in different ways or "faces" according to specific situations and groups; it can be thought of as the "individualism" of poverty. Due to the gradually weakening protection of traditional families, clans, and other social organizations, people have to face such a risk of poverty at an individual level in the labor market. 
It is certain that risk coexists with individualism and globalism and that women appear to suffer greater uncertainty in this status. Therefore, women have started to escape restrictions from traditional private spaces but are still not fully integrated into public spaces, such as the labor market. Moreover, under individualism, classification operates well in the labor market. On the one hand, poverty is so individualized that almost everyone may experience poverty; on the other hand, women face a high risk of being disadvantaged by their position in the labor market hierarchy. According to different working statuses and household compositions, women experience different challenges, particularly migrant women and single working mothers. As mobility becomes more normal in the labor market, women have more opportunities to develop in a professional career; they may also no longer be protected by their original families due to migration or divorce.

Therefore, poverty is being redefined in the gender dimension and against the background of individualism and globalism. Women are more likely to be exposed to the risk of poverty when facing the deconstruction of the family and the flexibility and insecurity of the labor market. Based on this, the gendered tendency of in-work poverty builds exactly on the individualism in today's labor market. Gendered poverty calls for womenspecific perspectives in political decision-making or gender dimensions in the welfare system to cope with the individualist tendency in the labor market.

\section{Gendered tendency of in-work poverty}

Of the existing research on in-work poverty, a particular point of view on investigating different groups within (distinct) societies is often missing: the differences in the in-work poverty profiles between women and men, between rural and urban, or within different occupational sectors. Notably, the exploration of how gender and poverty interact is still insufficient in the relevant studies; the gender dimension has been absent for quite an extended period of the discussion. The argument for including the gender dimension in in-work poverty is that gender inequalities in the labor market indeed contribute to women's systematically higher risk of poverty (EIGE 2016). Consequently, "women in work" becomes a key for understanding the feminized tendency of poverty. Moreover, a female approach to in-work poverty is crucial for an in-depth focus on the clash among women, poverty, and work issues. This is a research area to be developed.

First, it is necessary to acknowledge how the development of in-work poverty is gendered. In fact, a gendered tendency is prevalent in all spheres, such as employment and housework allocation; even in poverty, it becomes more obvious in the labor market and is manifested as a gender pay gap, gender pension gap, employment gap (e.g., across the EU and even in Asia, women's average employment rate is generally below men's employment rate) or gender-biased occupational segregation (e.g., phenomenon of feminized nonstandard jobs and women-specific low-wage jobs). It is hidden in private spaces (e.g., the gendered division of care and family responsibilities), social norms (e.g., traditional stereotypes for male-breadwinner model), or in the policy framework of decision-making. The abovementioned "systematic" gender "differences" further disadvantage women's situation in both the private and public spheres. Therefore, when we observe the phenomenon of the working poor in depth, similarly, in-work poverty shows a gendered or women-specific tendency. 
Following the changes and reconstruction of the labor market against the backdrop of globalization and individualism, women in the rich regions of the world (in several European nations) have been reported to be "hit harder" by the crisis and budget cuts in welfare support during recent years (Jones 2010; Perrons 2015); this is also true in the developing world (in some East Asian nations, e.g., China). At the EU level, the economic crises since 2008 had an aggravating effect on working poverty (Fraser et al. 2011). Moreover, such a feminized trend has become more severe and intensified since the economic crisis. In fact, almost one in four people live at risk of poverty or social exclusion; in particular, women account for more than half of the population (European Institute for Gender Equality's Report 2016).

Second, such a gendered tendency for the working poor is closely linked to the economic crisis, recession, and relevant welfare response. Given the different roles played in private and economic activities, it is widely recognized that women have been influenced by crises and welfare responses that are not the same as those of men (European Commission 2015). Since 2010, the recession in Europe has caused increasing numbers of migrants and minority women to be located in the margins of the labor market; it has also happened in Southeast Asia and China. The economic crises transformed labor markets by creating more jobs without paying attention to the quality of employment and have thus pushed people into more unstable and deregulated working conditions. This has indirectly promoted the increase of low-quality employment (more precarious, temporary, and less paid) and absorbed numbers of women under living pressure who migrated from rural to urban areas or transferred jobs from the public sector to the private sector. Therefore, the job creation approach without paying attention to the quality of employment does not increase women's economic independence.

The impact of the above development challenges the work-life balance for women across the life cycle and reveal their disadvantaged status in the labor market. Increasingly, discrimination and inequality lurk in the labor market with a tendency toward precarious working conditions, feminized informal sectors, and reductions in social protections (public care services, family and children benefits), which have had a negative impact on women's participation in the labor market and increased women's share of unpaid domestic work. It seems that women are more likely to be employed in such unstable working arrangements and are more negatively influenced than men, and, thus, are more likely to fall into the poverty trap of low-wage jobs (Stratigaki 2015). In contrast to the traditional male-breadwinner model, an increasing number of women are becoming "active people" in society with precarious employment status and suffering from gender gaps in pay and career promotion. In this sense, in-work poverty seems to impact women more than men in the labor market in both developed and developing countries.

\section{Conclusion}

Understandings cut deeper than explanations, which in this review may go beyond simply one explanation in a specific, limited sphere. We argue that explanations of in-work poverty presuppose an understanding of complex relations between poverty, gender, and status in private and public spheres. Roles and power in hierarchies within households and the labor market, as well as gender norms, are likely to affect 
those suffering from a higher risk of poverty. Therefore, the gender dimension and the life-course perspective contribute to a better understanding of in-work poverty.

A gender analysis of poverty must examine the interaction of socioeconomic relations with the features of the family, labor market, and the welfare state (Bennett and Daly 2014). The analyses, then, not only understand gendered working conditions in the labor market, such as the gender pay gap and gender employment segregation but also should be interconnected with the gender disparity of housework allocation. Moreover, poverty can be measured by one's position or level of wealth (EIGE 2016). In-work poverty can also be understood in relative terms of an individual's status in the labor market hierarchy, which impacts women more with their precarious employment (low pay and part-time work). From a life-cycle perspective, the gender disparity of housework allocation contributes to women's unequal access to the labor market, and poverty affects the working poor more due to limited access to power, wealth, and cultural resources.

Furthermore, in-work poverty reflects people's living and working conditions in private and public spaces, thereby revealing people's disparities or unequal access to well-being in the labor market. If we study women in relation to in-work poverty from a life course perspective, the generally used measurements of the working poor at the household level are not suitable; they lack the consideration of possible unequal resource allocation within the household and do not reveal the full gender dimension. With these measurements, women are usually underrepresented among the working poor (Eurofound 2010b; EIGE 2016). However, when individual poverty for men or women is measured, new gender issues and relevant problems rise to the surface and are linked to the fact that in-work poverty makes sense in the relationship between people and their work and is, first of all, individual (Meulders and O'Dorchai 2013). To conclude, on a gender dimension, the analysis of in-work poverty has to go beyond household-dimensioned economic poverty; it is necessary to inspect women's lives in the private and public spheres and explore female in-work poverty as an independent issue.

\section{Abbreviations \\ EIGE: European Institute for Gender Equality; EU: European Union; ILO: International Labour Organization; IWP: In-work poverty; US: United States.}

Acknowledgements

I thank the editor and reviewers for their expertise and assistance in improving the manuscript.

\section{Authors' contributions}

The research was conducted by one author, the author confirms sole responsibility for the conception and design, data collection, analysis and interpretation of results, and manuscript preparation. The author read and approved the final manuscript.

\section{Authors' information}

Jinghong Liu is an assistant professor in Zhou Enlai School of Government, Nankai University in Tianjin, China. The author got PhD in Université Libre de Bruxelles, Belgium, and has been researching on the topic of gendered in-work poverty in comparative perspective since the doctoral training. The author's research interests focus on the topic of in-work poverty, comparative social policy, and especially for the comparison of social policies between Europe and China. Recent publications: Liu, J. (2020). Fortress besieged: The female working poor in the evolution of Chinese social closure. Asian Journal of Women's Studies, 26(3), 279-300. Liu, J. (2018). Cross-national research on female working poor in Belgium and China. Chinese Sociological Dialogue, 3(2), 96-132. 


\section{Funding}

This research was funded by [Major project of National Social Science Foundation in China] under Grant [number 20ZDA068]. The funder had no role in study design, data collection and analysis, decision to publish, or preparation of the manuscript.

\section{Availability of data and materials}

Not applicable.

\section{Declarations}

\section{Competing interests}

The authors declare that they have no competing interests.

Received: 11 June 2021 Accepted: 14 December 2021

Published online: 04 January 2022

\section{References}

Abbott, W.F. 1980. Commentary: When will academicians enter the ranks of the working poor? Academe 66 (6): 349-353.

Alonzo, D. 2012. Meeting Basic Needs on Low Income Wages in a Local Setting in Southern California: Experiences of the Working Poor (Doctoral dissertation).

Andress, H.J., and H. Lohmann, eds. 2008. The working poor in Europe: Employment, poverty and globalization. Cheltenham: Edward Elgar Publishing

Bane, M.J., and D.T. Ellwood. 1991. Is American business working for the poor? Harvard Business Review 69 (5): 58-62.

Bardone, L., and Guio, A. C. 2005. Statistics in focus: Population and social conditions. In-Work Poverty. 5.

Baskin, D. 1982. Mental illness and the working poor. The Journal of Behavioral Health Services and Research 9 (2): 29-31.

Beck, U. 2004. A critical introduction to risk society. London: Pluto Press.

Beck, U. 2014. The brave new world of work. New York: John Wiley \& Sons.

Belcher, J.R. 1994. How to help the working poor develop assets. Journal of Sociology \& Social Welfare 21: 57

Bennett, F., and M. Daly. 2014. Poverty through a gender lens: Evidence and policy review on gender and poverty. Barnett Papers in Social Research. Oxford: University of Oxford.

Berger, Stefan, and Harasty, Claire. 2002, World and regional employment prospects: Halving the World's working poor by 2010. ILO Employment Paper, 2002/38.

Bluestone, B., W.M. Murphy, and M.H. Stevenson. 1973. Low wages and the working poor, vol. 22. Ann Arbor: Institute of Labor and Industrial Relations, University of Michigan-Wayne State University.

Boschmann, E.E. 2011. Job access, location decision, and the working poor: A qualitative study in the Columbus. Ohio Metropolitan Area. Geoforum 42 (6): 671-682.

Buchbinder, H. 1983. The working poor, wage earners and the failure of income security policies.

Burkhauser, R. V. 2014. Why minimum wage increases are a poor way to help the working poor (No. 86). IZA Policy Paper.

Callero, P.L. 2017. The myth of individualism: How social forces shape our lives. Lanham: Rowman \& Littlefield.

Cappellari, L. 2002. Do the'working poor'stay poor? An analysis of low pay transitions in Italy.

Castel, R. 2011. The crisis of 'organized modernity.'In European and Chinese sociologies: A new dialog, ed. Laurence Roulleau-Berger and Li. Peil, 65-74. Leiden: Brill.

Cheung, K.C.K., and K.L. Chou. 2016. Working poor in Hong Kong. Social Indicators Research 129 (1): 317-335.

Chilman, C.S. 1991. Working poor families: Trends, causes, effects, and suggested policies. Family Relations 40: 191-198.

Cormier, D., and C. Craypo. 2000. The working poor and the working of American labor markets. Cambridge Journal of Economics 24 (6): 691-708.

Craypo, C., and D. Cormier. 2000. Job restructuring as a determinant of wage inequality and working-poor households. Journal of Economic Issues 34 (1): 21-42.

Crettaz, E. 2014. Working Poor. In Encyclopedia of quality of life and well-being research, 7226-7230. Dordrecht: Springer.

Dafermos, Y., and C. Papatheodorou. 2012. Working poor, labor market and social protection in the EU: A comparative perspective. International Journal of Management Concepts and Philosophy 6 (1-2): 71-88.

Danziger, S., and P. Gottschalk. 1986. Work, poverty, and the working poor: A multifaceted problem. Monthly Labor Review 109 (9): 17-21.

Darling, H., and K. Bass. 1987. The uninsured: Federal policy and the working poor. Business and Health 4 (3): 36-40.

De Wolff, A. 2000. The face of globalization: Women working poor in Canada. Canadian Woman Studies 20 (3): 54.

Desmond, M., and C. Gershenson. 2016. Housing and employment insecurity among the working poor. Social Problems 63 (1): 46-67.

Duggan, D. 1969. Still forgotten-working poor. Nation 208 (23): 724-726.

Duncan, G.J., A.C. Huston, and T.S. Weisner. 2007. Higher ground: New hope for the working poor and their children. New York: Russell Sage Foundation.

Eggebeen, D.J., and D.T. Lichter. 1991. Race, family structure, and changing poverty among American children. American Sociological Review 56: 801-817.

Escosteguy, A.C., and L.L. Coutinho. 2017. The rise of the working poor within the Brazilian mediascape: The mythology of social inequality's disappearance. In Brazil: Media from the Country of the Future, 37-51. Emerald Publishing Limited: Bingley. 
Eurofound. 2010. Absence from work—Belgium. European Observatory of Working Life. Retrieved from http://www.eurof ound.europa.eu/observatories/eurwork/comparative-information/national-contributions/belgium/absence-fromwork-belgium

Eurofound. 2010. Working poor in Europe. Dublin, European Foundation for the Improvement of Living and Working Conditions.

Eurofound. 2017. In-work poverty in the EU. Publications Office of the European Union, Luxembourg.

European Commission. 2015. Visions for gender equality. Publications Office of the European Union. Retrieved from http://ec.europa.eu/justice/gender-equality/les/documents/vision_report_en.pdf

European Institute for Gender Equality. 2016. Poverty, gender and intersecting inequalities in the EU: Review of the implementation of Area A: Women and Poverty of the Beijing Platform for Action. Publications Office of the European Union.

Eurostat. 2016. EU statistics on income and living conditions (EU-SILC) methodology-in-work poverty, Statistics Explained, web page, accessed 12 July 2017.

Fields, G.S. 2012. Working hard, working poor: a global journey. Oxford: Oxford University Press.

Figart, D., and J. Lapidus. 1995. A gender analysis of U.S. labor market policies for the working poor. Feminist Economics 1 (3): 60-81.

Frankovic, K.A. 1976. The working poor: Minority workers in low-wage, low-skill jobs. By Dennis P. Sobin. (New York: Kennikat Press, 1973. Pp. 194. \$8.50.). American Political Science Review 70 (1): 226-227.

Fraser, N., R. Gutiérrez, and R. Peña-Casas, eds. 2011. Working poverty in Europe. Berlin: Springer.

Fritsch, N. S. and Verwiebe, R. 2008. Labor market flexibilization and in-work poverty: A comparative analysis of Germany, Australia and Switzerland. In Handbook on in-work poverty

Gautié, Jérome., and Sophie Ponthieux. 2016. Employment and the working poor. In The Oxford handbook of the social science of poverty, ed. David Brady and Linda M. Burton. Oxford: Oxford University Press.

Gibbon, P., ed. 1995. Structural adjustment and the working poor in Zimbabwe: Studies on labour, women informal sector workers and health. Uppsala: Nordic Africa Institute.

Gilbert, M. 2000. Identity, difference, and the geographies of working poor women's survival strategies. In Gendering the City: Women, boundaries, and visions of urban life, 65-87. Lanham: Rowman \& Littlefield.

GHK \& Fondazione G. Brodolini. 2011. Final synthesis report: Evaluation of the European social fund's support to gender equality. Brussels: European Commission, DGEMPL.

Goerne, A. 2011. In-work-poverty in Europe. A comparative perspective. In Working Poverty in Europe, 15-45. London: Palgrave.

Greenberg, D. H. 1971. Income guarantees and the working poor in New York City: The effect of income maintenance programs on the hours of work of male family heads.

Griffith, D., and E. Kissam. 1995. Working poor: Farmworkers in the United States. Philadelphia: Temple University Press.

Greenberg, D.H., and Kosters, M. 1970. Income guarantees and the working poor: The effect of income maintenance programs on the hours of work of male family heads.

Grootings, P. 1986. Technology and work: A topic for East-West comparison. In Technology and work: East-West comparison, 273-301. London: Taylor \& Francis.

Gulati, L. 1981. Profiles in female poverty: a study of five poor working women in Kerala. Delhi: Hindustan Publishing Corporation.

Gutiérrez, R., M. Ibáñez, and A. Tejero. 2011. Solving the gender paradox of the working poor: Opening the household black box by individualising in-work poverty risks. In Working poverty in Europe, ed. Neil Fraser and Rodolfo Gutierrez. London: Palgrave Macmillan.

Haveman, R.H., I. Lurie, and T.W. Mirer. 1973. Earnings supplementation plans for "working poor" families: An evaluation of alternatives. Madison: Institute for Research on Poverty, University of Wisconsin.

Hepworth, H.P. 1982. The working poor: Wage earners and the failure of income security policies. Toronto: James Lorimer Limited.

Hylton, M.O.B. 1996. Some preliminary thoughts on the deregulation of insurance to advantage the working poor. Fordham Urban Law Journal 24: 687.

Ilsøe, A. 2016. From living wage to living hours-the Nordic version of the working poor. Labor \& Industry: A Journal of the Social and Economic Relations of Work 26 (1): 40-57.

International Labor Organization. 2017. World employment and social outlook: Trends 2017. International Labor OfficeGeneva. Retrieved from http://www.lo.org/wcmsp5/groups/public/---dgreports/---dcomm/---publ/documents/ publication/wcms_541211.pdf.

International, L. O. I. 1996. Women swell ranks of working poor. World of Work: THe Magazine of the ILO 17:4

Jacobson, B.H. 1975. Radical revision of the minimum wage: The dual economy and the elimination of working poverty. Doctoral dissertation, Reed College.

Jones, J. 2010. An invisible crisis? Women's poverty and social exclusion in the European Union at a time of recession. European Women's Lobby, Oxfam International.

Kachel, D. 1988. Working however, poor. New York: JSTOR.

Karagiannaki, E., and Platt, L. 2015. The changing distribution of individual incomes in the UK before and after the recession.

Kelly, J. 1986. Women, history, and theory: The essays of Joan Kelly. Chicago: University of Chicago Press.

Keyserling, L. H. 1966. Role of wages in a great society, stressing minimum-wage gains to help the working poor. In Conference on Economic Progress.

Kim, M. 1998. The working poor: Lousy jobs or lazy workers? Journal of Economic Issues 32 (1): 65-78.

Kim, J., and S. Lee. 2007. Female working poor and labour market policies. In Women's Studies Forum. Seoul: Korean Women's Development Institute.

Kim, M., and T. Mergoupis. 1997. The working poor and welfare recipiency: Participation, evidence, and policy directions. Journal of Economic Issues 31 (3): 707-728.

Klein, B.W., and P.L. Rones. 1989. A profile of the working poor. Monthly Labor Review 112: 3. 
Kossek, E.E., M. Huber-Yoder, D. Castellino, and J. Lerner. 1997. The working poor: Locked out of careers and the organizational mainstream? The Academy of Management Executive 11 (1): 76-92.

Lagarenne, C., \& Legendre, N. 2000. The working poor in France: Personal and family factors. Economie \& Statistique.

Leys, C. 1973. Interpreting African underdevelopment: Reflections on the ILO Report on Employment, Incomes and Equality in Kenya. African Affairs 72 (289): 419-429.

Levitan, S.A., and I. Shapiro. 1987. The Working Poor: A missing element in welfare reform. Washingston: Graduate Institute for Policy Education and Research, Graduate School of Arts and Sciences, George Washington University.

Lipman, F. J. 2003. The working poor are paying for government benefits: Fixing the hole in the anti-poverty purse. Wisconsin Law Review, 461.

Lohmann, H. 2006. Working poor in Western Europe: What is the influence of the welfare state and labour market institutions? In Presentation at the 2006 Conference of the EuroPanel Users Network (EPUNet), 8-9.

Lohmann, H. 2009. Welfare states, labour market institutions and the working poor: A comparative analysis of 20 European countries. European Sociological Review 25 (4): 489-504.

Lohmann, H., and I. Marx, eds. 2018. Handbook on in-work Poverty. Cheltenham: Edward Elgar Publishing.

Lohmann, H., Nieuwenhuis, R., and Elgar, I. M. E. (2017). Single-parent families and in-work poverty.

Mack, R. (2014). A measure of help for the working poor: A study of the effects of the minimum wage on welfare enrollment in the United States, 1990-2011.

Majid, N. 2001. The size of the working poor population in developing countries. ILO. Employment sector.

Marchal, S., Marx, I., and Verbist, G. 2017. Income support policies for the working poor.

Maria Stratigaki. 2015. The positive impact of a gender sensitive approach to the fight against poverty. Main causes on female poverty. European Parliament.

Marx, I. and Nolan, B. 2012. In-work poverty. GINI Discussion Paper No. 51. Amsterdam Institute for Advanced Labor Studies, Amsterdam.

Marx, I., J. Vanhille, and G. Verbist. 2012. Combating in-work poverty in Continental Europe: An investigation using the Belgian case. Journal of Social Policy 41 (1): 19-41.

McKnight, A., Steward, K., Himmelweit, S.M., and Palillo, M. 2016. Low pay and in-work poverty: preventative measures and preventative approaches. European Commission Evidence Review.

McMurray, G. L., and Kazanjian, D.P. 1982. Day care and the working poor: The struggle for self-sufficiency.

Meulders, D., and S. O'Dorchai. 2013. The working poor: Too low wage or too many kids. American International Journal of Contemporary Research 3 (7): 30-46.

Miller, S.M. 1970. Prospects for the working poor. London: New Generation.

Meulders, D., and S.P. O'Dorchai. 2014. The working poor: Too low wage or too many kids? American International Journal of Contemporary Research 3 (7): 30-46.

Moser, C., and K. Young. 1981. Women of the working poor. IDS Bulletin 12 (3): 1-9.

Murray, C. 1987. In search of the working poor. The Public Interest 89: 3.

National Council of Welfare. 1987. Welfare in Canada: The tangled safety net, 117. Ottawa: Minister of Supply and Services Canada, November.

Nickson, J.W., and H.B. Karp. 1974. Deprivation, Incentives and Mental Illness. American Journal of Economics and Sociology 33 (2): 113-125.

Nolan, H.R., and B. Christie III. 2017. Access through altruism: A community-based free outpatient surgery program for the working poor in the United States. Journal of Perioperative Practice 27 (6): 141-144.

Noponen, H. 1992. Loans to the working poor: A longitudinal study of credit, gender and the household economy. International Journal of Urban and Regional Research 16 (2): 234-251.

OECD. 2009. In-work poverty: What can governments do? Policy Brief, September (2009). https://www.oecd.org/els/ 43650040.pdf.

Paugam, S. 2017. Poverty and attachment regimes in modern societies. In Soziale Bildungsarbeit-Europäische Debatten und Projekte, 9-27. Wiesbaden: Springer Fachmedien Wiesbaden.

Pearce, D. 1978. The feminization of poverty: Women, work, and welfare. Urban Social Change Review 11: 128-136.

Peña-Casas, R., and D. Ghailani. 2011. Towards individualizing gender in-work poverty risks. In Working poverty in Europe, 202-231. London: Palgrave Macmillan.

Peña-Casas, R., and Latta, M. 2004. Working poor in the European Union. Office for Official Publications of the European Communities.

Perrons, D. 2015. The effects of the crisis on female poverty. European Parliament report.

Petry, J. 2014. Assessing the effects of internal devaluation strategy in the wake of the Eurozone crisis: An analysis of labour market flexibilisation and the working poor in Europe.

Ponthieux, S. 2010. Assessing and analyzing in-work poverty risk. Income and living conditions in Europe, 307.

Porras, L. 2015. Rebuscadores: Indignation about the Legal misrecognition of the most vulnerable segment of the working poor in Bogotá.

Pradella, L. 2015. The working poor in Western Europe: Labor, poverty and global capitalism. Comparative European Politics 13 (5): 596-613.

Puente, S. 1997. Race, ethnicity, and working poverty: A statistical analysis for metropolitan Chicago.

Remesh, B.P. 2009. 1 Rethinking social protection for India's working poor in the unorganised sector.

Richards, J., and Sang, K. 2018. The intersection of disability and in-work poverty in an advanced industrial nation: The lived experience of multiple disadvantage in a post-financial crisis UK. Economic and Industrial Democracy, $0143831 \times 17750474$.

Riphenburg, C.J. 1996. Structural adjustment and the working poor in Zimbabwe: Studies on labour, women informal sector workers and health.

Rogers, Harrell R., Jr. 1990. Poor women, poor families: The economic plight of American female-headed households. Armonk, NY: M. E. Sharpe.

Saltzman, A., and Kidder, A. E. 1974. Patterns of mobility of working poor. Journal of Transportation Engineering 100(Proc. Paper 10760). 
Sassen, S. 2007. A sociology of globalization. New York: W.W. Norton \& Company Inc.

Scardigli, V. 1970. Social policies and the working poor in France. Centre de recherche et de documentation sur la consommation.

Schiller, B. 1994. Who are the working poor? The Public Interest 115: 61.

Scholz, J.K. 1993. Tax policy and the working poor: The earned income tax credit. Focus 15 (3): 1-12.

Seccombe, K., and C. Amey. 1995. Playing by the rules and losing: Health insurance and the working poor. Journal of Health and Social Behavior 36: 168-181.

Shapiro, I. 1989. Labouring for less: Working but poor in rural America.

Shapiro, I., and Greenstein, R. 1990. Fulfilling work's promise: Policies to increase incomes of the rural working poor.

Shea, J.R., and Richard, J.E. 1971. Wage rate differences among the working poor. In Proceedings of the Social Statistics Section. American Statistical Association.

Shiang, J. 1990. Fighting poverty: Wage subsidy for the working poor. Doctoral dissertation, University of Texas at Austin. Siddiqui, A.M.A.H., ed. 1990. Labour laws and the working poor. Geneva: International Labour Organization.

Shipler, D.K. 2005. The working poor: Invisible in America. New York: Vintage.

Shiu, P.A. 1989. Work and family: Policies for the working poor. Harvard Journal on Legislation 26: 349.

Sieverding, M. 2012. A life course perspective on social protection among the working poor of Egypt.

Smith, J.A. 1985. Working poor lack medical assistance. California Nurse 81 (6): 6.

Smith, A., A. Stenning, A. Rochovská, and D. Światek. 2008. The emergence of a working poor: Labor markets, neoliberalisation and diverse economies in post-socialist cities. Antipode 40 (2): 283-311.

Stellman, J.M. 1988. The working environment of the working poor: An analysis based on workers' compensation claims, census data and known risk factors. Women \& Health 12 (3-4): 83-101.

Strengmann-Kuhn, W. 2002. Working poor in Europe: A partial basis income for workers?

Strier, R., Z. Eisikovits, L. Sigad, and E. Buchbinder. 2016. Working men views of poverty: Ethnic perspectives. Men and Masculinities 19 (5): 480-502.

Sundaram, K., and S.D. Tendulkar. 2002. The working poor in India: Employment-poverty linkages and employment policy options, vol. 4. Geneva: International Labor Office, Recovery and Reconstruction Department.

Tella, A. 1971. The hours of work and family income response to negative income tax plans. The Impact on the Working Poor.

Thebault, K. 1992. The Minnesota HealthRight Act: Health care access for the working poor or mere insurance reform? Journal of Emergency Nursing 18 (5): 431-433.

Thiede, B.C., D.T. Lichter, and S.R. Sanders. 2015. America's working poor: Conceptualization, measurement, and new estimates. Work and Occupations 42 (3): 267-312.

Tickamyer, A. R. 1992. The working poor in rural labor markets: The example of the Southeastern United States. Rural poverty in America, 41-61.

U.S. Bureau of Labor Statistics. 2014. A Profile of the Working Poor, 2014. https://www.bls.gov/opub/reports/workingpoor/2014/home.htm.

Vance, J.D. 2016. Hillbilly elegy — A memoir of a family and culture in crisis. New York, NY: HarperCollins.

Van Til, S.B. 1975. Low wages and the working poor. New York: JSTOR.

Van Lancker, W. 2012. The European world of temporary employment: Gendered and poor? European Societies 14 (1): 83-111.

Wachtel, D.D. 1965. The working poor. Ann Arbor: University of Michigan.

Wachtel, H.M., and C. Betsey. 1972. Employment at low wages. The Review of Economics and Statistics 54: 121-129.

Weitzman, B.C., and C.A. Berry. 1992. Health status and health care utilization among New York City home attendants: An illustration of the needs of working poor, immigrant women. Women \& Health 19 (2-3): 87-105.

Wicks-Lim, J. 2012. The working poor: A booming demographic. New Labor Forum 21 (3): 17-25.

Willen, D. 1988. Women in the public sphere in early modern England: the case of the urban working poor. The Sixteenth Century Journal 58: 559-575.

Yiyin, Yang. 2012. Guanxilization or categorization: Theoretical considerations based on two case studies. European and Chinese Sociologies: A New Dialog 2012: 163-173.

\section{Publisher's Note}

Springer Nature remains neutral with regard to jurisdictional claims in published maps and institutional affiliations. 